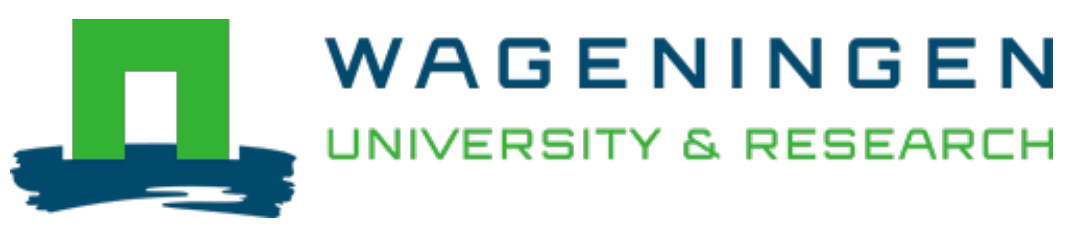

\title{
The Blessings of Medicine? Patient Characteristics and Health Outcomes in a Ugandan Mission Hospital, 1908-1970
}

\author{
Social History of Medicine \\ Doyle, Shane; Meier Zu Selhausen, F.P.; Weisdorf, Jacob \\ https://doi.org/10.1093/shm/hky125
}

This article is made publicly available in the institutional repository of Wageningen University and Research, under the terms of article $25 \mathrm{fa}$ of the Dutch Copyright Act, also known as the Amendment Taverne. This has been done with explicit consent by the author.

Article 25 fa states that the author of a short scientific work funded either wholly or partially by Dutch public funds is entitled to make that work publicly available for no consideration following a reasonable period of time after the work was first published, provided that clear reference is made to the source of the first publication of the work.

This publication is distributed under The Association of Universities in the Netherlands (VSNU) 'Article $25 \mathrm{fa}$ implementation' project. In this project research outputs of researchers employed by Dutch Universities that comply with the legal requirements of Article $25 \mathrm{fa}$ of the Dutch Copyright Act are distributed online and free of cost or other barriers in institutional repositories. Research outputs are distributed six months after their first online publication in the original published version and with proper attribution to the source of the original publication.

You are permitted to download and use the publication for personal purposes. All rights remain with the author(s) and / or copyright owner(s) of this work. Any use of the publication or parts of it other than authorised under article $25 \mathrm{fa}$ of the Dutch Copyright act is prohibited. Wageningen University \& Research and the author(s) of this publication shall not be held responsible or liable for any damages resulting from your (re)use of this publication.

For questions regarding the public availability of this article please contact openscience.library@,wur.nl 


\title{
The Blessings of Medicine? Patient Characteristics and Health Outcomes in a Ugandan Mission Hospital, 1908-1970
}

\author{
Shane Doyle**, Felix Meier zu Selhausen* and Jacob Weisdorf ${ }^{\dagger}$
}

\begin{abstract}
Summary. This article sheds new light on the impact and experience of western biomedicine in coIonial Africa. We use patient registers from Western Uganda's earliest mission hospital to explore whether and how Christian conversion and mission education affected African health behaviour. A data set of 18,600 admissions permits analysis of patients' age, sex, residence, religion, diagnoses, duration of hospitalisation and treatment outcomes. We document Toro Hospital's substantial geographic reach, trace evolving treatment practices and highlight significant variation in hospitalbased disease incidence between the early colonial and early postcolonial periods. We observe no relationship between numeracy and health outcomes, nor religion-specific effects concerning hygiene-related infections. Christian conversion was associated with superior cure rates and shorter length of stay and with lower incidence of skin diseases and sexually transmitted infections (STIs). However, our findings indicate that STI incidence was linked to morality campaigns and that clinicians' diagnoses were influenced by assumptions around religious groups' sexual behaviour.
\end{abstract}

Keywords: Africa; medical history; missionary medicine; religion; sexually transmitted infections

From the 1920s, and especially from the 1950s, recorded mortality levels across tropical Africa fell substantially, contributing to exceptionally high rates of population increase. ${ }^{2}$ While this broad trend is generally accepted, there remains considerable disagreement about the timing of mortality change, the relevant significance of curative and preventive medical interventions and the related question of whether increased longevity was ac-

\footnotetext{
${ }^{*}$ Department of Economics, University of Sussex, Falmer BN1 9RH, UK. E-mail: fm272@sussex.ac.uk.

** School of History, University of Leeds, Leeds LS2 9JT, UK.

${ }^{\dagger}$ Department of Economics, University of Southern Denmark, Campusvej 55, 5230 Odense M, Denmark.
}

\begin{abstract}
Shane Doyle is a Professor of African History at the University of Leeds. He was the Director of the Leeds University Centre for African Studies, 2014-18 and is currently a co-editor of the Journal of African History. His most recent book, Before HIV (OUP, 2013) won the African Studies Association's Ogot Award.

Felix Meier zu Selhausen is a British Academy Postdoctoral Fellow (2017-20) at the University of Sussex, working on the project 'Conversion out of Poverty? Exploring the origins and long-term Consequences of Christian Missionary Activities in Africa'. Previously, he was a Visiting Fellow at the University of Sussex and Mountains of the Moon University, during his post-doctoral research at the University of Southern Denmark on 'The Economic History of Christian Africa'.

Jacob Weisdorf is a Professor of Business and Economics at the University of Southern Denmark. He has previously worked at the University of Copenhagen and held visiting positions at European University Institute, Florence, LUISS University, Rome, the Paris School of Economics, and Utrecht University. He is a previous editor of the Scandinavian Economic History Review.
\end{abstract}

\footnotetext{
1'The blessings of medicine' are referred to in The Mission Hospital, 1935, 39, 447, 82.
${ }^{2}$ Shane Doyle, Before HIV: Sexuality, Fertility and Mortality in East Africa, 1900-1980 (Oxford: Oxford University Press, 2013), 1-2.
}

(C) The Author(s) 2019. Published by Oxford University Press on behalf of the Society for the Social History of Medicine. doi:10.1093/shm/hky125

Advance Access published 16 March 2019 
companied by substantial declines in morbidity. ${ }^{3}$ Although the decline in mortality rates can be viewed as a core achievement of the modern state in Africa, ${ }^{4}$ in reality, the main source of western healthcare for most Africans, for most of this period, was missionary medicine. ${ }^{5}$

While there can be no questioning the impressive reach of medical mission, some commentators have emphasised the unevenness of its focus, impact and quality. As Michael Jennings has demonstrated, colonial governments often defended their own medical record by contrasting the public health-oriented aims of state-provided healthcare with those of mission medicine. Tanganyika's Medical Department, for example, argued in 1937 that, whereas it was 'concerned with the mass of the people and particularly with the prevention of the spread of disease', the missions' focus was 'more particularly with the individual and with, so far, the curative aspect' ${ }^{6}{ }^{6}$ Such a viewpoint was sustained by scholars who consider that the prioritisation of curative care reflected medical mission's strategic interest in employing healing as a gateway to personal conversion. ${ }^{7}$ Medical missionaries themselves made no secret of the ultimate goal of physical healing, with the secretary to the Church Missionary Society's (CMS) medical committee admitting that church clinics were 'used as heavy artillery ... in the less responsive fields' of missionisation. Medical mission depicted itself as the ultimate example of Christ-like caring for the afflicted, but clerics' perspective was more functional, assuming that healthcare would bring new souls into the church because illness created a captive audience. ${ }^{8}$ In some cases, this determination to reach the maximum number of potential converts seemingly affected the quality of care, the spiritual benefits of the healing encounter legitimising a second-rate mission health service. ${ }^{9}$

Missionary medicine may indeed have been primarily 'a tool for evangelisation', but its approach was not necessarily undifferentiated. Missions felt an obligation to expand their activities beyond the individual, where they identified opportunities to offer relief for disadvantaged groups such as those suffering leprosy, the blind and the crippled, 'biblical manifestations of disease and misery'. ${ }^{10}$ Maternal and child health was another area

\footnotetext{
${ }^{3}$ Dennis Cordell and Joel Gregory, African Population and Capitalism: Historical Perspectives (Boulder, CO: Westview, 1987); Jack Caldwell, 'The Social Repercussions of Colonial Rule: Demographic Aspects', in Albert Adu Boahnen, ed, UNESCO General History of Africa, VII (London: UNESCO, 1985), 458, 476-80; Meredith Turshen, 'The Impact of Colonialism on Health and Health Services in Tanzania', International Journal of Health Services, 1977, 7, 7-35; Alexander Moradi, 'Towards an Objective Account of Nutrition and Health in Colonial Kenya: A Study of Stature in African Army Recruits and Civilians, 1880-1980', Journal of Economic History, 2014, 69, 3, 719-54; Sara Lowes and Eduardo Montero, 'The Legacy of Colonial Medicine in Central Africa', Harvard University Working Paper, 2018.

${ }^{4} \mathrm{Cf}$. John Iliffe, Africans: the History of a Continent (Cambridge: Cambridge University Press, 2007), 24750.
}

${ }^{5}$ Norman Etherington, Missions and Empire (Oxford: Oxford University Press, 2005), 261-84.

${ }^{6}$ Quoted in Michael Jennings, '"Healing of Bodies, Salvation of Souls": Missionary Medicine in Colonial Tanganyika, 1870s-1939', Journal of Religion in Africa, 2008, 38, 1, 27-56, 37.

${ }^{7}$ O. Akerele, I. Tabidzadeh and J. McGilvray, 'A New Role for Medical Missionaries in Africa', WHO Chronicle, 1976, 30, 5, 175-80; David Hardiman, 'Introduction', in David Hardiman, ed, Healing Bodies, Saving Souls: Medical Missions in Asia and Africa (Amsterdam: Brill, 2006), 25.

${ }^{8}$ Quoted in Andrew F. Walls, "'The Heavy Artillery of the Missionary Army": The Domestic Importance of the Nineteenth-Century Medical Missionary', Studies in Church History, 1982, 19, 287-97.

${ }^{9}$ Charles Good, The Steamer Parish: The Rise and Fall of Missionary Medicine on an African Frontier (Chicago: University of Chicago Press, 2004), 407.

${ }^{10} \mathrm{lbid}$., 8; Kathleen Vongsathorn, '" First and Foremost the Evangelist"? Mission and Government Priorities 
pioneered by missions across Africa. ${ }^{11}$ In Uganda, for example, the CMS alone had established 23 maternity and child welfare centres as early as 1932. These clinics were tasked with improving local morality and serving as 'a beacon light of hygienic village life, in the midst of the surrounding insanitary darkness'. ${ }^{12}$ By the 1950s, one in five pregnant women in Uganda gave birth in a mission clinic, with double that number receiving antenatal advice. ${ }^{13}$ Rural centres' referral of high-risk cases to major maternity hospitals was so efficient by the 1930s that their maternal and neonatal mortality rates were similar to those found in England and Wales. ${ }^{14}$ As Jennings has noted, the depiction of medical mission as solely focused on the curative and individual seems then to be only partly accurate, as does the reputation for inadequate care. ${ }^{15}$

This article analyses unique data contained in in-patient registers from Uganda's oldest rural mission hospital relating to 16,525 individuals between 1908 and $1970 .^{16}$ It offers several new perspectives on medical mission and healthcare provision in the African past more generally. First, by examining the in-patient registers of a large rural referral hospital, we are able to analyse the impact and reach of generalist missionary medicine. Toro Hospital was for most of the colonial period the largest medical institution in western Uganda, providing both preventive and curative care for a remarkably large area. Secondly, we analyse in more detail than has hitherto been possible the effectiveness of mission healthcare, highlighting variation in cure rates, hospital mortality and average length of stay (ALOS) over the period 1908-70. Our findings indicate that while hospital mortality rates remained broadly constant, patient throughput increased enormously, and some of the most debilitating conditions endemic to the region were almost eradicated by the end of our period. Hospitals appear to have had a greater indirect than direct impact on overall mortality levels and contributed to a changing pattern of morbidity through preventive and curative care. Thirdly, the registers highlight the surprising representativeness of the patients who chose to attend, and were admitted by, the hospital, in terms of age, sex, religion and residence, and permit an analysis of medical outcomes by these patient characteristics. Fourthly, we are able to show how the relative frequency of different diseases and disease categories changed over time. In particular, we are able to evaluate the extent to which missionaries' fixation with hygiene and sexual morality was reflected in the relative frequency of conditions such as worms and sexually transmitted

for the Treatment of Leprosy in Uganda, 1927-48', Journal of Eastern African Studies, 2012, 6, 3, 54460; Akerele, Tabidzadeh and McGilvray, 'New Role', 175-80; Jennings, 'Healing', 35.

${ }^{11}$ Nancy Rose Hunt, A Colonial Lexicon: Of Birth Ritual, Medicalization and Mobility in the Congo (Durham: Duke University Press, 1999); Megan Vaughan, Curing Their IIls: Colonial Power and African Illness (Stanford: Stanford University Press, 1991).

${ }^{12}$ Roy Billington, A Tune on Black and White Keys: Partnership in Healing: the Story of Mengo Hospital (London: Janus, 1993), 29; Albert Cook, Report of the Lady Coryndon Maternity Training School, 1933, CMS Archive, Birmingham, M/Y/A7 1931-5.

${ }^{13}$ Uganda Protectorate, Annual Report of the Medical Department, 1958 (Entebbe: Government Printer, 1959).
${ }^{14}$ Albert Cook, 'Recent history', Cook Archive, Mulago Hospital, Kampala, c.1933.

${ }^{15}$ Jennings, "'Healing"'.

${ }^{16}$ For other studies based on hospital registers, see B. Risse and J. H. Warner, 'Reconstructing Clinical Activities: Patient Records in Medical History', Social History of Medicine, 1992, 5, 2, 183-205; V. Hionidou, "'It was a Bridge from life to Death": Hospitals During the Food Crisis, Greece 19411944', SHM, 2009, 22, 2, 361-85; Jonathan Pritchett and Myeong-Su Yun, 'The In-Hospital Mortality Rates of Slaves and Freemen: Evidence from Touro Infirmary, New Orleans, Louisiana, 18551860', Explorations in Economic History 2009, 2, 46, 241-52. Toro was located in a very small town, serving a predominantly rural population. 
infections (STIS) among their Protestant converts, when compared with other groups. This in turn sheds new light on whether and how Christian conversion and mission education affected African health behaviour and on the skewed diagnosis of STIs in early colonial Uganda, both subjects, which have received considerable academic interest. ${ }^{17}$ Crucially, we are able to demonstrate that diagnostic patterns varied sharply under different missionary doctors, particularly in relation to STIs.

\section{Toro Hospital}

Until the 1920s, medical care and training in Uganda was largely in missionary hands. Missionary medicine remained the most prevalent form of healthcare in rural Uganda as late as the 1950s. ${ }^{18}$ The Anglican CMS pioneered medical care in Uganda, with Albert Cook opening Mengo Hospital in Kampala in 1897. Anglican missionaries' evangelical and medical work quickly spread from the British Protectorate's largest city to the Toro Kingdom in Western Uganda. In Toro's capital, Fort Portal, the CMS opened a small dispensary that soon served around 60 out-patients a day. ${ }^{19}$ At 1,500m altitude, Fort Portal, located along the northern foothills of the Rwenzori Mountains, which separated Uganda from the Belgian Congo, represented one of the healthier environments in Uganda. Relatively cool temperatures limited the prevalence of malaria, multiple rivers and streams provided easy access to water, while fertile, rain-fed volcanic and alluvial soils were suitable for intensive agriculture. Much of the Toro kingdom, however, was lower lying, characterised more by swamps than mountain streams. As Fort Portal's dispensary evolved into the leading hospital of western Uganda, its patient community came to reflect this geographical diversity.

The Fort Portal dispensary's fortunes changed with the arrival in 1901 of Ashton Bond. In 1903, he transformed the existing dispensary building and founded Toro Hospital, Uganda's first fully equipped medical mission outside Kampala. In his first 10 months, Bond treated 96 in-patients and saw 7,500 out-patients. In 1904, a more ambitious hospital with a thatched roof and mud walls was built with 34 beds. ${ }^{20}$ From the beginning, Toro Hospital reflected the ambition not only of missionary medicine but also of the kingdom's indigenous elite. Local chiefs donated all 12 beds in Bond's first hospital, located adjacent to the royal palace. ${ }^{21}$ The king of Toro, Kasagama, was reportedly fascinated by the technical prowess of the missionary doctor, who rarely missed an opportunity to provide spectacular examples of miraculous intervention. Soon after the new hospital was opened adjacent to the king's palace, Kasagama 'half out of curiosity and

\footnotetext{
${ }^{17}$ On conversion, see Hardiman, Healing; Terence Ranger, 'Godly Medicine: The Ambiguities of Medical Mission in Southeastern Tanzania 1900-45', pp. 5-18, Social Science \& Medicine, 1981, 15, 26177; Mark Harrison, Margaret Jones, and Helen Sweet (eds), From Western Medicine to Global Medicine: The Hospital Beyond the West (Hyderabad, India: Orient Blackswan, 2009). On STIs, see Megan Vaughan, 'Syphilis in Colonial East and Central Africa: The Social Construction of an Epidemic', in Terence Ranger and Paul Slack, eds, Epidemics and Ideas (Cambridge: Cambridge University Press, 1992), 269-302; Carol Summers, 'Intimate
}

Colonialism: The Imperial Production of Reproduction in Uganda, 1907-1925', Signs, 1991, $16,4,787-807$.

${ }^{18}$ Luise White, "'They Could Make Their Victims Dull": Genders and Genres, Fantasies and Cures in Colonial Southern Uganda', American Historical Review, 1995, 100, 5, 1379-402.

${ }^{19}$ Kenneth Ingham, The Kingdom of Toro in Uganda (London: Methuen, 1975), 83.

${ }^{20}$ Ashton Bond, Twenty Years in Toro Hospital (Eastbourne: Bennett, 1924), 3.

${ }^{21}$ Ashton Bond, Mercy and Truth, 1905, 9, 97, 16-20. 
Table 1. Toro Hospital statistics, 1903-65

\begin{tabular}{rrrrrr}
\hline Year & In-patients & Out-patients & Beds & Operations & In-patients at Toro Government Hospital \\
\hline 1903 & 96 & 7,500 & 12 & 40 & \\
1906 & 576 & 25,000 & 38 & 105 & \\
1909 & 671 & 20,175 & 65 & 173 & \\
1918 & 621 & 25,561 & 100 & 166 & $405^{\mathrm{a}}$ \\
1928 & 1,015 & 22,801 & 127 & 330 & 896 \\
1935 & 1,250 & 15,000 & 80 & 43 & $671^{\mathrm{b}}$ \\
1938 & 837 & 13,592 & 80 & 43 & na \\
1940 & 686 & na & 80 & na & na \\
1949 & 1,252 & na & 70 & 0 & na \\
1955 & 183 & na & 33 & 0 & na \\
1965 & 727 & 10,000 & 40 & na & \\
\hline
\end{tabular}

Sources: Toro Hospital In-patients Registers, Mercy and Truth and The Mission Hospital (various issues), Uganda Medical and Sanitary Report 1931, 1936, 1939.

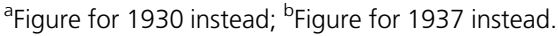

half out of a real desire that his people should derive the fullest benefit from the "doctor's wisdom"', volunteered to have an ulcer lanced under chloroform. 'From that time surgery ... became a kind of fashionable epidemic. ${ }^{22}$

As shown in Table 1, patient demand rose rapidly. In 1909, the hospital increased its capacity to 65 beds, admitted 671 in-patients, performed 170 operations and attended to 20,175 outpatients. ${ }^{23}$ At the same time, Bond, having gained a diploma in tropical medicine from the Liverpool School, expanded his hospital work to include visits to the outlying villages and government prisons and training Ugandan men to become medical assistants. ${ }^{24}$ The mud-and-wattle hospital was replaced in 1911 by a new, larger hospital with brick walls and floors and an operating theatre hygienically finished with cement. The building, constructed with finance and labourers supplied by Toro's chiefs and king, could 'be seen for many miles round, the largest and most distinctive feature in the landscape'. ${ }^{25}$ This showpiece of secular progress and spiritual expansion maintained five public wards, with 26 beds each in the men's and women's wards, eight beds in the children's ward and six in the obstetric and babies' ward. While the public wards broadly reflected the age and sex profile of the wider population, the hospital's overall structure reflected local hierarchies of status and wealth, unsurprisingly given its reliance on patient fees and elite patronage. Three private wards were reserved for the relatives of chiefs, South Asians and Europeans. Yet, the medical mission aimed at social transformation. Alongside its commitment to relieving suffering, the hospital was regarded as a primary

\footnotetext{
${ }^{22}$ Heike Behrend, Resurrecting Cannibals: The Catholic Church, Witch-hunts, and the Production of Pagans in Western Uganda (London: Boydell and Brewer, 2011), 182; William Foster, 'Doctor Albert Cook and the Early Days of the Church Missionary Society's Medical Mission to Uganda', Medical History, 1968, $12,4,325-43$.

${ }^{23}$ Mercy and Truth, 1910, 14, 163.
}

${ }^{24}$ On CMS doctors' secular medical roles, see Yolana Pringle, 'Crossing the Divide: Medical Missionaries and Government Service in Uganda, 1897-1940', in Anna Greenwood, ed, The Colonial Medical Service in British Africa (Manchester: Manchester University Press, 2016), 19-38.

${ }^{25}$ Bond, Twenty, 5. 
route to conversion, with Cook, head of Uganda's Anglican medical mission, viewing the process of healing as a unique opportunity for evangelisation. ${ }^{26}$ Importantly, Toro Hospital was not reserved for existing converts, but was open to all irrespective of religious belief, with daily attendance at religious instruction being a pre-condition for medical treatment. ${ }^{27}$

In 1923, after 21 years of medical service, Dr Bond left Toro Hospital. His successor, Dr A.T. Schofield (1923-28), intensified the hospital's outreach work, opening a dispensary branch at Kijura, and two maternity and welfare centres at nearby Rubona and Kahangi, staffed by local women trained at the CMS's Maternity Training School in Kampala. ${ }^{28}$ This required the doctor to make regular visits to supervise the midwives and dressers who sustained the rural medical mission, acting as a 'walking advertisement for the (medical) work' and laying the foundations for the CMS's pioneering development of health centres focusing on preventive medicine in the 1950s. ${ }^{29}$

Toro's monopoly on biomedical provision was relatively short-lived. In 1912, the Catholic White Sisters opened a dispensary in Fort Portal, which evolved into Virika Hospital in 1915. ${ }^{30}$ However, Virika under the White Sisters remained limited in physical and technical capacity, run by nurses rather than a doctor, and limited to 18 beds. ${ }^{31}$ Only from 1963 did Virika develop the full functions of a hospital. The colonial administration of Toro District meanwhile relied completely on the CMS hospital until 1930 when it opened a permanent government hospital in Fort Portal, reflecting growing secularism and welfarism. ${ }^{32}$ Initially, with 40 beds, 405 in-patient admissions and 30 operations, the government hospital's treatment capacity was less than half that of Toro's, despite free treatment. ${ }^{33}$ By 1938, however, it was on a par with the CMS hospital, which had by this time begun a long struggle to maintain standards (see Table 1).

Following Dr Leakey's resignation in 1935, after 7 years' service, Toro Hospital remained without a resident doctor for most of the next 30 years, relying on local dressers' daily oversight by local government doctors and periodical visits from Mengo's clinicians. ${ }^{34}$ Quality of treatment and patient numbers were, thus, broadly maintained until 1952, however, financial pressures and staffing crises saw the hospital close in 1956. Soon its grounds 'reverted to bush'. ${ }^{35}$ Following a sustained local campaign, the hospital

\footnotetext{
${ }^{26}$ Mercy and Truth, 1904, 95, 8, 338.

${ }^{27}$ Foster, 'Albert', 330.

${ }^{28}$ See Figure A2 in Online Appendix for a map; The Mission Hospital, 1930, 34, 391, 178. The CMS marriage registers from St. John's Cathedral (19111970) in Fort Portal, which report brides' occupations, show nurse/midwives increased in number from 3 in the 1920s to 11 in the 1960s. Cf. Felix Meier zu Selhausen, 'Missionaries and Female Empowerment in Colonial Uganda: New Evidence from Protestant Marriage Registers 1880-1945', Economic History of Developing Regions, 2014, 29, 1, 74-112.

${ }^{29}$ John Iliffe, East African Doctors: A History of the Modern Profession (Cambridge: Cambridge
}

University Press, 1998), 23; A. T. Schofield, 'Some Patients at Toro', The Mission Hospital, 1927, 31.

${ }^{30}$ Louise Pirouet, Black Evangelists: The Spread of Christianity in Uganda, 1891-1914 (London: Collings, 1978) 61.

${ }^{31}$ Iliffe, Doctors, 20; Holy Family Virika Hospital, Centenary and Golden Jubilee Celebrations 19122014 (Virika, 2014).

${ }^{32}$ Uganda Medical and Sanitary Report 1930, 39.

${ }^{33}$ Uganda Protectorate, Annual Report Medical and Sanitary Report, 1930 (Entebbe: Government Printer, 1931), Table F.

${ }^{34}$ The Way of Healing, 1940, 44, 509, 509.

${ }^{35}$ CMS Historical Record, 1944, 50; The Church Missionary Outlook, June 1964. 


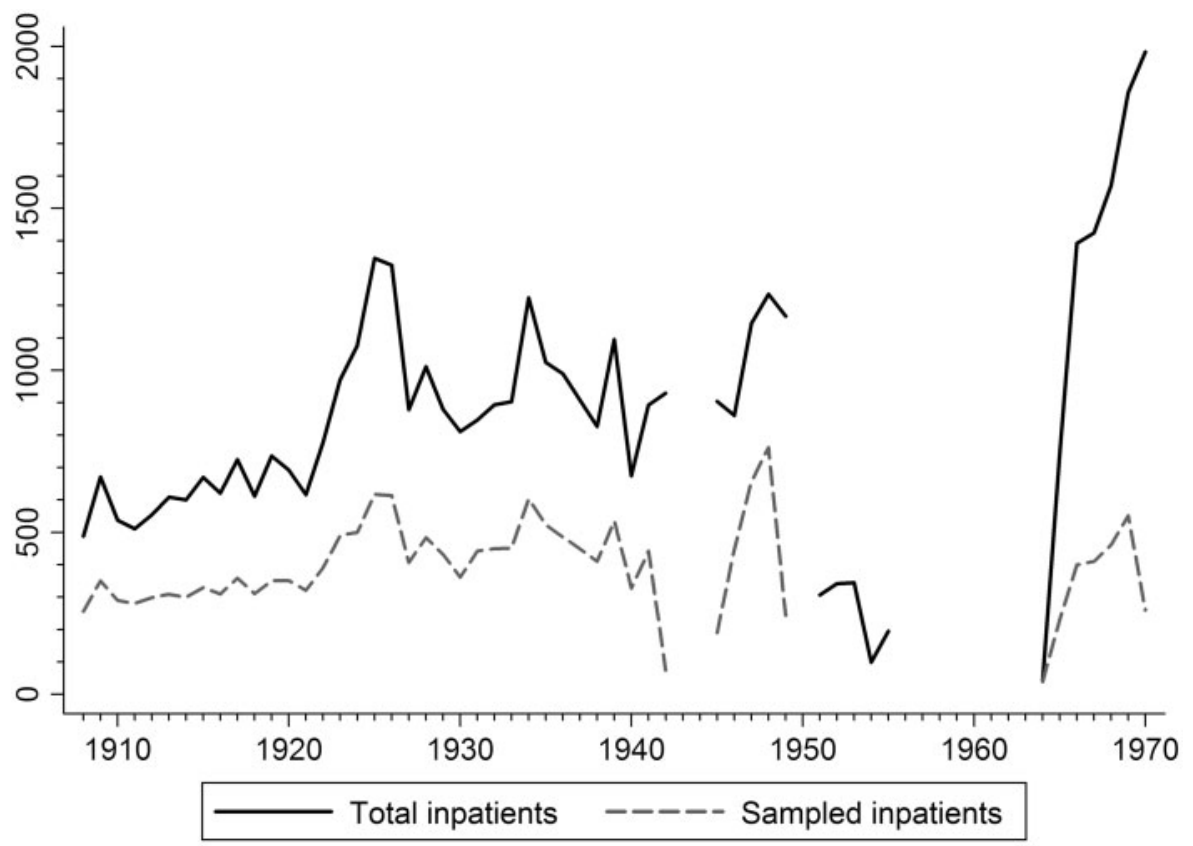

Fig. 1. Total and sampled in-patients from Toro Hospital, 1908-1970. The temporary increase in the number of patients in 1924-25 and 1933-34 are due to short-term increases in bed capacity (see Table 1). Patient records for the years 1942, 1945, 1949 and 1951 do not cover the full year. Toro hospital was closed during 1956-63.

was rebuilt with finance from the Ugandan government and the Toro royal court. Now indigenised under Church of Uganda management, the institution reopened in 1964 with Robin Church as resident doctor, under the name 'Kabarole Hospital'. ${ }^{36}$ Deliberately smaller than in its heyday, the hospital nonetheless rapidly expanded admissions beyond what had been achieved in previous decades (Figure 1), as demand for in-patient treatment accelerated across Uganda during its first decade of independence. ${ }^{37}$ This history of expansion and contraction, cooperation and competition, and godly ambition and secular support provides essential context for the evaluation of this hospital's medical records.

\section{Data}

\section{Collection and Sampling}

Our primary data source is the in-patient registers of Toro Hospital. These registers contain systematic recording of African in-patients' health in English, including patients' dates of hospital admission and discharge, diagnosed disease(s), name of bed (i.e. sponsor), treatment result at discharge, duration of hospital stay and, in some instances,

\footnotetext{
${ }^{36}$ Ruanda Notes, 1961, 156, 42-43. For simplicity, the following analysis refers to the institution as Toro Hospital for the entire period up to 1970.

${ }^{37} 1960$ Ruanda Mission, Toro Archive, Folder 27(2), Med. 8, Mountains of the Moon University, Fort Portal.
} 
additional remarks by the doctor. The registers further report patients' personal details, including their names, age, sex, religion and place of residence. ${ }^{38}$

The survival of individual-level data on African patient characteristics dating back to the beginning of the 20th century and continuing into the post-colonial era is extremely unusual. ${ }^{39}$ Figure 1 shows the trend in total number of in-patients and the sample used in this study. In total, 35,522 in-patients were admitted to Toro Hospital between 1908 and 1955 and 9,015 during 1964-70. For our purpose, we have sub-sampled every second in-patient admitted between 1908 and 1949 and every fourth in-patient for the period between 1964 and 1970. The registers covering the initial years (1903-07) and 1943-44 were lost. The 1950-56 register survived but recorded neither patients' diseases nor their length of hospitalisation, reflecting the general decline of the hospital before its temporary closure in $1956 .{ }^{40}$ The most recent register made available to us for this study ended in 1970. In total, our dataset for 1908-49 includes 16,210 in-patients, while for 1964-70 it counts 2,353 in-patients. ${ }^{41}$

Some of the in-patient files were unsuited for our analysis. First, we omitted anyone who was not of African descent. Of 18,563 sampled in-patients, we excluded 48 European patients and 27 South Asians, as we are interested in the impact of the medical mission on the indigenous population. ${ }^{42}$ Secondly, the hospital did not keep a separate maternity register, and, thus, Toro's in-patient registers included normal maternity cases (i.e. deliveries without complications). We omitted those patients from the analysis (831 of 18,488), as their condition was not disease-related. ${ }^{43}$ Thirdly, to avoid over-representation of repeated admissions, we included patients' first admission but excluded them when re-attending with the same diagnosis (236 of 17,657). The total sample, thus, comes to 15,316 inpatients for the period 1908-49 and 2,105 for admissions between 1964 and 1970 .

\section{The Coding of Diseases}

We have coded each disease diagnosis according to the World Health Organization's International Statistical Classification of Diseases, Injuries, and Causes of Death, Version 10-2010 (ICD). The ICD is the standard diagnostic classification system for epidemiology, health management and clinical purposes, translating diagnoses of diseases and other health problems into 21 general categories. Globally, it is used to monitor the incidence and prevalence of diseases and other health problems, providing a picture of the general health situation of countries and populations. ${ }^{44}$ Table 2 shows the full tabulations of

\footnotetext{
${ }^{38}$ See Figure $A 1$ in the Online Appendix for an example of Toro's patient register. The registers are stored in Kabarole Hospital's medical records centre.

${ }^{39}$ One rare example of case record analysis from an early 20th-century hospital is E. M. Fèvre et al., 'Reanalyzing the 1900-1920 Sleeping Sickness Epidemic in Uganda', Emerging Infectious Diseases, 2004, 10, 4, 567-73.

${ }^{40}$ CMS Historical Record, 1952, 24.

${ }^{41}$ We deliberately sampled only a quarter of inpatients for 1964-1970 because admissions rose so rapidly after independence.

${ }^{42}$ The very small number of Europeans and South Asians indicates that this register was the record of admission onto the public 'African' wards and not the private segregated wards.
}

${ }^{43}$ Complications of pregnancy and birth remain in the data set.

${ }^{44}$ For previous use of ICD in classifying death causes from missionary records, see S. W. Hackel, 'From Ahogado to Zorrillo: External Causes of Mortality in the California Missions', The History of the Family, 2012, 17, 1, 77-104. The possibility of using alternative coding systems, such as the International List of Causes of Death or the Bertillon List, was rejected as the advantages of using contemporary coding systems were limited by their inconsistency over time. See Irvine Loudon, 'On Maternal and Infant Mortality 1900-1960', Social History of Medicine, 1991, 4, 1, 32. 


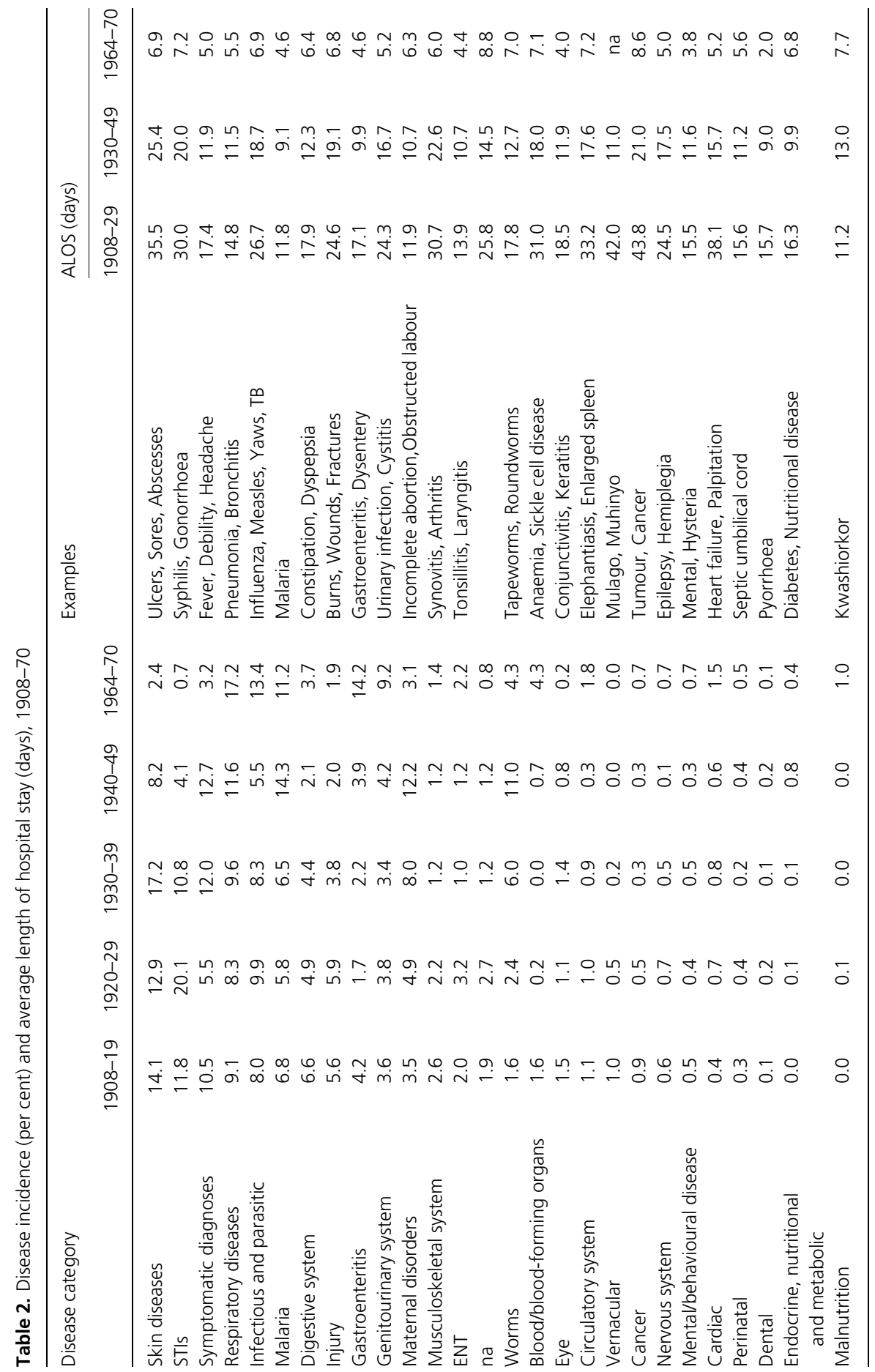


disease categories in this study and examples from the original records used to make these classifications. Due to this article's focus on some specific conditions (such as malaria and STIS), Table 2 is organised into 26 categories and sub-categories. A combination of diseases in the same patient was found in 7.3 per cent cases. We classified each entry separately. Overall, we have been able to classify 98.1 per cent of diseases.

The ICD is used to translate diagnoses of diseases and associated health problems from words into an alphanumeric code, which permits analysis of the data. Its creators acknowledge the difficulties of creating a system of classification that reflects the complexity of disease and still more the challenges involved in applying this universal classification across the diverse languages and medical traditions found in contemporary societies. ${ }^{45}$ Inevitably, the retrospective application of any medical classificatory system will bring additional problems due to the use of outdated terminology and diagnostic conventions within historic registers. That medical staff in Toro were encountering patients whose concepts and vocabulary of disease causation, sensation and expected treatment were commonly at odds with those of western biomedicine further complicated the process of diagnosis and subsequent categorisation. These problems can be mitigated to some degree by detailed analysis of changing diagnostic practices and assumptions over time, as will be shown below in relation to STIs. ${ }^{46}$

\section{Who Came to the Clinic?}

Evaluation of the data collected for this article first requires an analysis of the representativeness of the mission hospital in-patient. Medical mission, given its self-justification as a route to conversion and a demonstration of Christianity's devotion to the afflicted, tended to portray itself as inclusive. Yet, mission institutions' evangelical ethos may have limited their appeal, while mission medical care's reliance on fees may have caused the poor to rely on the free-to-user state provision. It is necessary to consider whether the fervent Anglican character of the hospital deterred non-Christians and non-Protestants and whether people of lower economic or social status, including women and children, were less likely to access the hospital.

Soon after Toro Hospital opened, its doctor claimed that 'The only qualification for admission is illness', ${ }^{47}$ and 'all were received into the same ward without distinction of class or religion'. ${ }^{8}$ Overall, while poverty appears not to have deterred patients in Toro Hospital's early decades, it does seem to have become a factor by the 1950s. In 1905, a report noted that 'in-patients . . have been from amongst all classes, some being chiefs and chiefs' wives. Others are among the poorest of the peasants. . Some bring a fowl or some eggs, others a string of shells, and some few bring a rupee. But the majority of the people are so poor that they have very little to give'. ${ }^{49}$ By 1915 , a minimum charge of one cent was imposed, though it was claimed this was more to deter those without illness (itself a marker of the hospital's success) rather than to raise revenue and that the

\footnotetext{
${ }^{45} \mathrm{WHO}$, International Statistical Classification of Diseases and Related Health Problems, 10, 2 (Geneva: WHO, 2016) 191-201.

${ }^{46}$ For an important discussion of the problems inherent in historical reconstruction, see Adrian Wilson, 'On

the History of Disease Concepts: The Case of Pleurisy', History of Science, 2000, 38, 271-319.

${ }^{47}$ Tenth Annual Report of the Toro Medical Mission (London: CMS, 1912), 11.

${ }^{48}$ Mercy and Truth, 1905, 9, 97, 17.

${ }^{49}$ Ibid. , 9, 97, 16-20.
} 
poor were 'forgiven even this small charge'. ${ }^{50}$ Thus, in 1919, patients were still 'drawn from every nationality and class of the community, from the king and queen ... down to the most degraded and wretched of the people.... But the poorest of the natives always form the largest number'. ${ }^{51}$ Over time, however, the level of subsidy from CMS headquarters in London reduced, so that the survival of the hospital required a shift in the local funding model, from one based on gifts, towards a regularised system of significant access fees. Previously, only chiefs had been required to pay the full costs of treatment. By 1937, 'native fees' amounting to $f 828$ exceeded those paid by Asian, European and private patients, while $f 1,742$ was charged for injections alone. ${ }^{52}$ These were substantial costs for a poor community to support. By the 1950s, although in-patient admission itself remained free, medication, surgery and 'special treatments' had to be paid for by all but the truly impoverished. Generally, the mission claimed that such charges had no deterrent effect. Thus, in 1950, it was reported that although 'fees have been increased to meet rising costs, and a charge is made for operations, injections and special drugs ... the people ... continue to come, ignoring the government hospital where treatment is free, and sometimes travelling long distances'. ${ }^{53}$ However, the same report elsewhere referred to an out-station whose fees deterred some potential patients who preferred free care at a government dispensary. And by 1952, fees, described as the hospital's core income, were raised again to meet costs. That year's report noted that 'the poverty of patients continue[s] to be a problem', suggesting that earlier generosity had tightened up and that the proportion of the poor within the patient community decreased from the 1950 s onwards. ${ }^{54}$

CMS hospitals sought to convince the entire Ugandan population that they were 'open to all, irrespective of religious creed'. The founding fathers of the Anglican medical mission in the region, Albert and Jack Cook, emphasised that hospital admission targeted not only unconverted indigenes but also Catholics, Hindus and Muslims. ${ }^{55}$ As Megan Vaughan has observed, the CMS recognised quickly the unique opportunities for conversion brought by the long-term, exclusivist control inherent in the institutionalisation of the sick. ${ }^{56}$ Yet anticipation of exposure to intense evangelisation was at most only a partial deterrent for non-Protestants, according to the admission registers. Figure 2 reveals that the overall religious make-up of the hospital's in-patients was surprisingly mixed. Anglicans were inevitably over-represented compared to Toro district, though less so compared to Fort Portal itself. In the 1930s, a decade when Christians made up 31 per cent of the district population, 31 per cent of in-patients were Anglican, 17 per cent Catholic, 4 per cent Muslim and 48 per cent were followers of African traditional religions. Even in the 1960s, by which time a large Catholic hospital was well-established in Fort Portal, still 30 per cent of Toro Hospital admissions were Catholic.

Even more striking than this remarkable religious diversity over a period of 60 years is the representativeness of the patient community by age and sex. Figure 3 shows that there is little evidence that families prioritised adult male health over that of women and

\footnotetext{
${ }^{50}$ Mercy and Truth 1915, 19, 228, 399.

${ }^{51}$ Mercy and Truth, 1919, 23, 264, 229.

${ }^{52}$ Educational Secretary General, 1937, 126/4, Archives of the Church of Uganda Online.

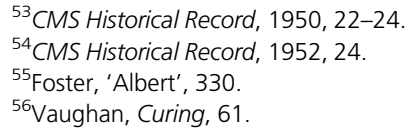

${ }^{53}$ CMS Historical Record, 1950, 22-24.

${ }^{55}$ Foster, 'Albert', 330.

${ }^{56}$ Vaughan, Curing, 61.
} 


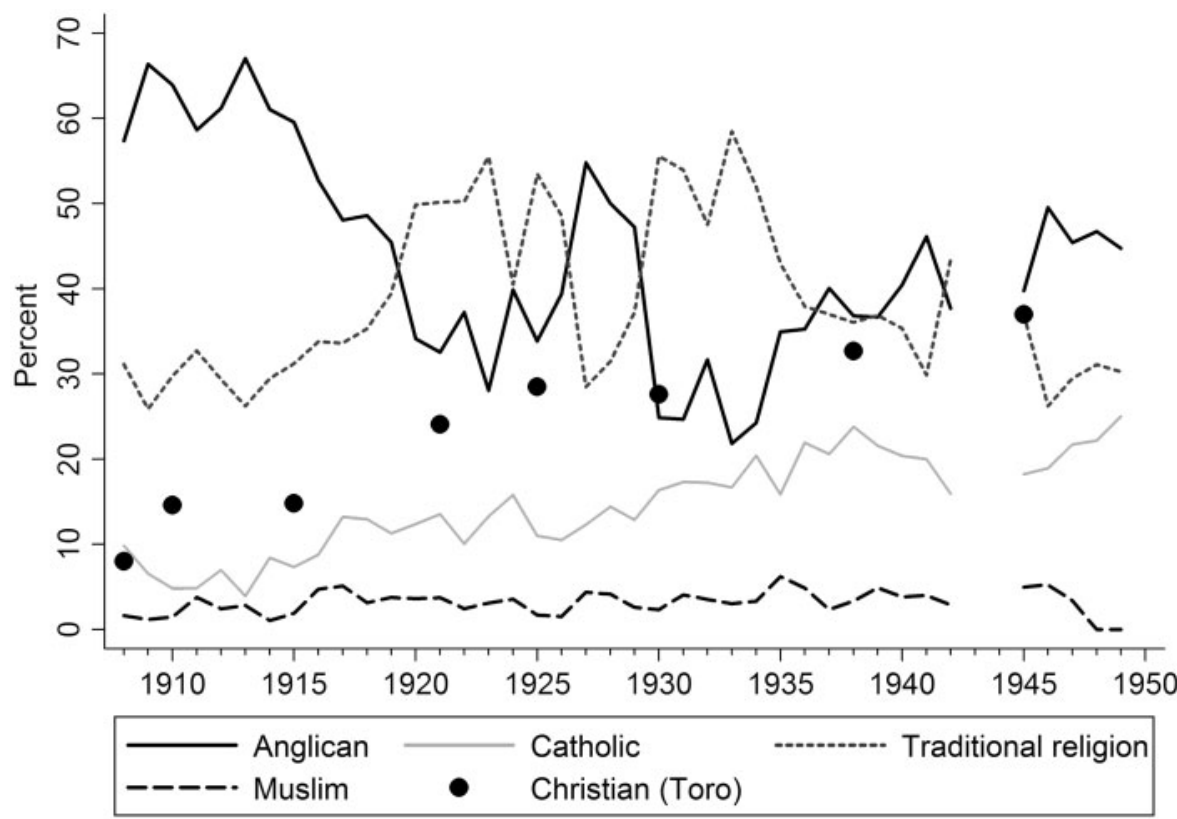

Fig. 2. Religious distribution within Toro Hospital in-patients and Toro district.

Sources: Christian share among Toro's population (black circles) from F. Meier zu Selhausen, 'Missionaries and female empowerment in colonial Uganda: New evidence from Protestant marriage registers, 18801945', Economic History of Developing Regions, 2014, 29, 1, 74-112; Ecclesiastical returns from Uganda Protectorate, Blue Books of Statistics (Kampala, 1908-45).

children. While some slight male advantage existed in the hospital's early years, overall, a clear majority of admissions were female. Even when maternity cases are excluded, 58 per cent of in-patients were female between 1930 and $1970 .{ }^{57}$

Meanwhile, Figure 4 shows that around 35 per cent of in-patients during the colonial period were younger than 16, a similar proportion to that recorded in the district censuses. About 18 per cent were younger than 5 years of age, a higher proportion than was the case among the general population, but reflective of the greater disease burden carried by the very young. In contrast, only 6 per cent of in-patients were older than 45 years of age, which in part reflected the region's low life expectancy, but perhaps also indicated that diseases of old age were under-represented among hospital admissions.

The final question regarding representativeness is to consider to what extent Toro Hospital's patients constituted an urban subset of a largely rural population. The first factor to consider is the nature of Fort Portal itself, which retained the character of a small town for most of the colonial period. In 1921, Fort Portal's population came to 1,824 with 31 permanent brick buildings. ${ }^{58}$ Two years earlier, medical missionaries reported 


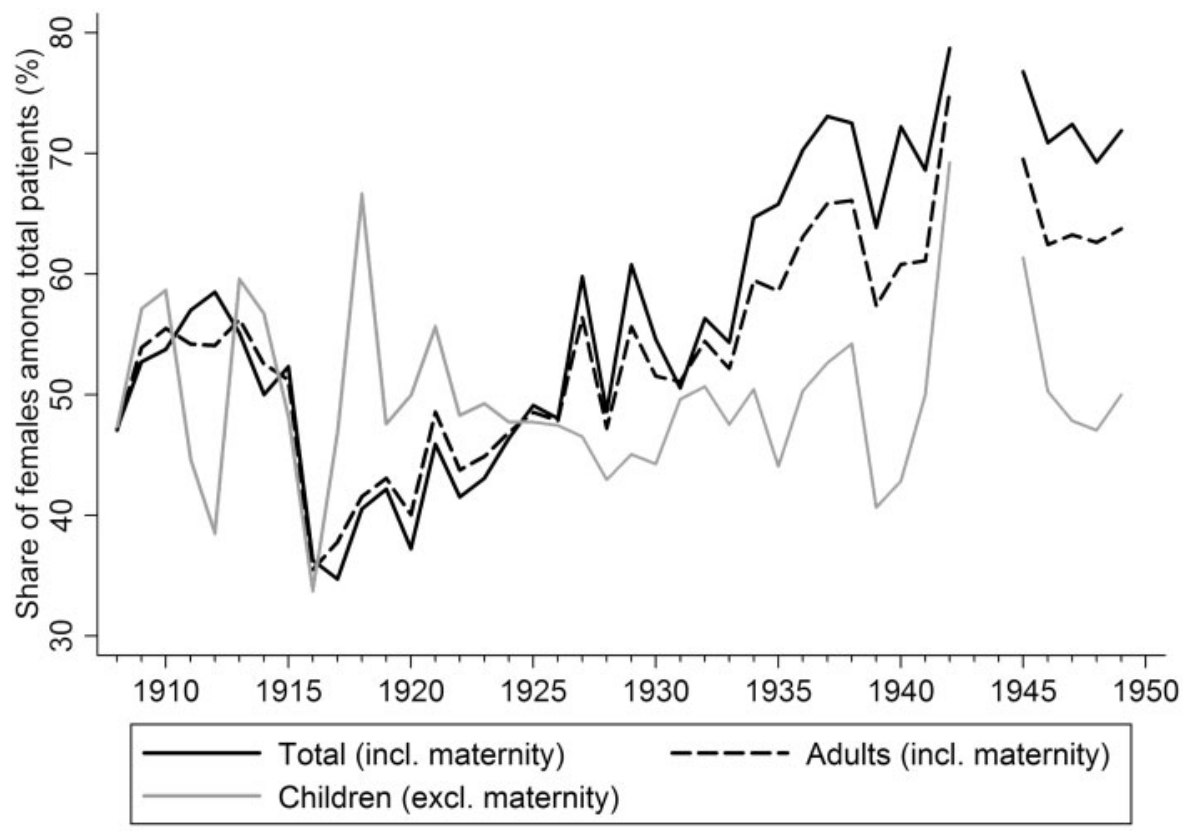

Fig. 3. Female in-patients among total Toro Hospital's in-patients (per cent), 1908-49.

that lions 'still pass through our gardens at night', 59 and the hospital's environs remained primarily agricultural for decades. ${ }^{60}$ Even in 1969, after two decades of rapid population growth across the district, Fort Portal's population was only 8,000. A further question relates to the reach of the hospital. Medical publications from colonial Uganda occasionally noted how far patients were prepared to travel to seek treatment. Toro was no exception. In 1919, Dr Bond reported that his Toro 'practice has a radius of a hundred miles'. ${ }^{61}$ John lliffe described a patient walking $160 \mathrm{~km}$ to Toro Hospital in 1928 drawn by the fame of Isaka, a dresser. ${ }^{62}$ Such claims continued into the 1950 s. 'The people... continue to come, ... sometimes travelling long distances (over 100 miles) for the advice of the African doctor at the mission hospital' ${ }^{63}$ Previous studies could provide little sense of whether rural or small town hospitals' catchment area really was this large or whether a few rare examples were used to propagate missionary impact.

To calculate how far the catchment area of the hospital extended, we geocoded patients' residential addresses using Google Earth and historical mission maps of Toro ${ }^{64}$ and calculated the Euclidean distance from patients' home to the hospital. We could assign geographical coordinates in 86.1 per cent of cases. ${ }^{65}$ Figure 5 presents patients'

\footnotetext{
${ }^{59}$ Mercy and Truth, 1919, 264, 23, 228.

${ }^{60}$ According to the 1921 Uganda population census, 75 per cent of Toro men were agriculturists, herders or labourers.

${ }^{61}$ Mercy and Truth, 1919, 23, 264, 228-30.
}

\footnotetext{
${ }^{62}$ lliffe, Doctors, 49.

${ }^{63}$ CMS Historical Record, 1950, 22-24.

${ }^{64}$ Pirouet, Black, 51.

${ }^{65}$ See Figure A2 in Online Appendix for a map of individual residence locations.
} 


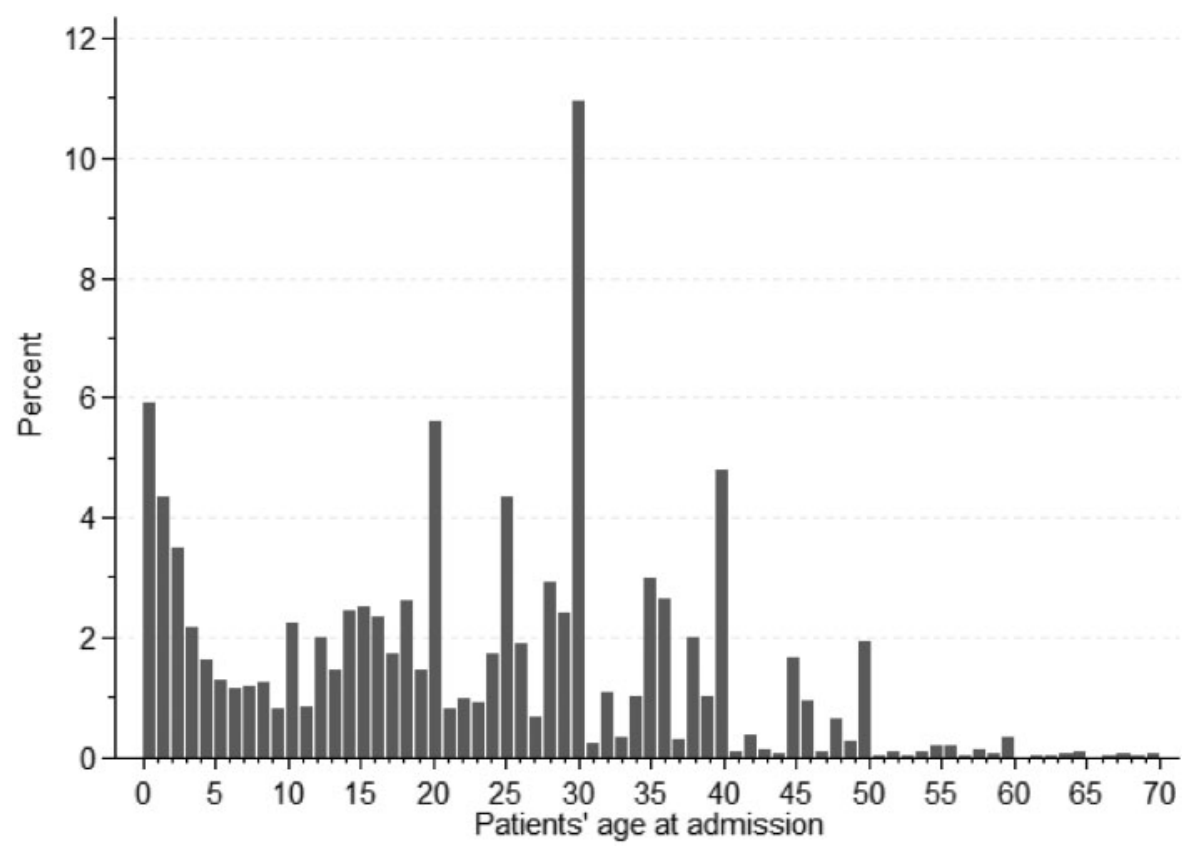

Fig. 4. In-patients' ages, 1908-1949. Truncated at 70 years of age because only 0.3 per cent of inpatients exceeded 70 years of age.

residence locations per $5 \mathrm{~km}$ grid-cell. Patients' average travel distance to the hospital fluctuated over time, rising as the hospital's renown grew and transport links expanded, falling as new medical facilities opened. Still, the overall pattern was consistent, with most patients being local, but a significant minority travelling surprising distances in search of treatment. Between 1908 and 1949, patients came from an average distance of $20.3 \mathrm{~km}$. About 62 per cent came from an immediate radius of $10 \mathrm{~km}$ from the hospital and 26 per cent within the range of $11-50 \mathrm{~km}$. Almost a quarter (23 per cent) came from more than a day's walk $(32 \mathrm{~km}$ ) away, with as many as 12 per cent of patients travelling more than $50 \mathrm{~km}$ to be treated at Toro. A deeper analysis of travel distance related to diseases and treatment outcomes is provided in Section 4.1. At this point, it is worth noting that while Christian and Muslim patients were unsurprisingly heavily clustered around Fort Portal, the overall conclusion must be that this urban hospital served a mainly rural population and that missionary medicine reached far beyond the immediate mission community. ${ }^{66}$ Overall then, it seems that the in-patient register is surprisingly representative of the regional population, but it must be emphasised that the hospital records relate only to individuals who chose to attend it and who were then admitted onto the wards. That patients' health strategies, and clinicians' decision-making, changed over time must be acknowledged in the interpretation of the data. 
1908-29

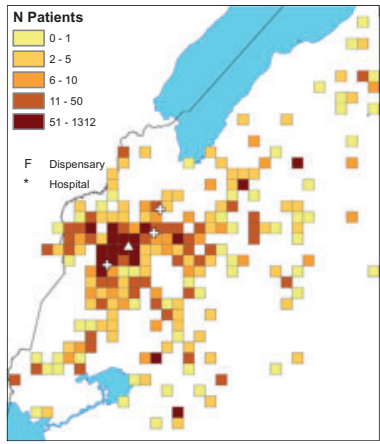

$1930-49$

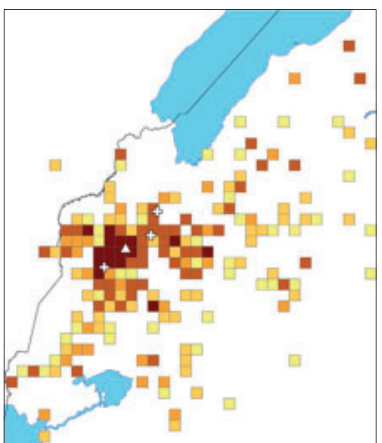

1964-70

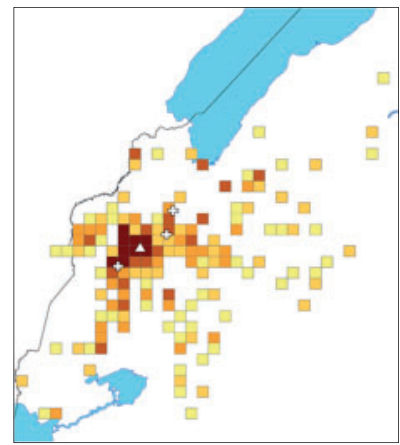

Fig. 5. Patients' residence locations. $5 \mathrm{~km} \times 5 \mathrm{~km}$ grid cells. Dispensaries (white crosses) denote Toro Hospital's welfare and maternal centres at Rubona (1927), Kahangi (1929) and Kijura (1930). Cells with the largest share of patients' homes receive the darkest shade, while those with the smallest share receive the lightest shade.

\section{Data Quality}

In this section, we draw some suggestive conclusions with regard to the value of the inpatient registers as a medical source. No information about laboratory testing was recorded, although presumably the hospital doctor would have been able to perform basic microscopy. The lack of electricity and trained technicians would have made more complex pathological analysis unlikely. It does not seem that the diagnosis of syphilis, discussed in detail in Section 4, was supported by the Kahn, VDRL or Wassermann tests before the 1960s. Overall, only 6.7 per cent of patients were diagnosed with more than one condition. This was almost certainly a gross underestimate, based on reports from Kampala's Mulago Hospital in the 1940s and 1950s, where research-oriented doctors who could rely on a full range of laboratory support observed that 'a combination of diseases in the same patient was a very common finding' ${ }^{67}$ The frequency with which coinfections or underlying conditions were recorded was extremely low during the tenure of Dr Ashton Bond (1903-23) at 1 per cent of all cases, but then increased sharply and steadily under his successors, reaching 18 per cent by 1949 . This suggests that a change in staff was accompanied by enhancement of the hospital's laboratory equipment, although there is suggestive evidence that the rising incidence of dual conditions also reflected a decline in initial diagnostic confidence. After 1923, a secondary condition was recorded most commonly where the primary diagnosis was simply a description of symptoms, such as 'cough', 'fever' or 'pain'. The most common secondary diagnoses in such situations were specific respiratory (46 per cent) or digestive (6 per cent) conditions, with worms (11 per cent) also significant.

\footnotetext{
${ }^{67}$ Jack Davies, 'Pathology of Central African Natives. Mulago Hospital Post Mortem Studies VII', East African Medical Journal, 1948, 25, 6, 228-35; Latimer Musoke, 'An Analysis of Admissions to the
}

Paediatric Division, Mulago Hospital in 1959', Archives of Disease in Childhood, 1961, 36, 187, 305-15. 
That 10 per cent of patients received a symptomatic diagnosis between 1908 and 1949 is perhaps indicative of both limited medical capacity within the hospital and a patient community whose understanding of disease causation and progression remained often significantly different from that of western biomedicine. ${ }^{68}$ It is though worth noting that Toro Hospital's doctors seem to have been relatively effective in diagnosing malaria, whose incidence peaked about 2 months after each rainy season (see Online Appendix Figure A4), in contrast to diagnoses of other common diseases whose frequency fluctuated marginally across the year (see Online Appendix Figure A5). Toro Hospital's bimodal pattern of malaria during the colonial period matches that recorded in the postcolonial era, when malaria testing facilities were substantially stronger. ${ }^{69}$

The registers do provide significant insights into changing patterns of illness and treatment in Uganda, but inevitably they cannot fully replicate disease prevalence. This is highlighted by the near absence of sleeping sickness cases in the records, as Ugandan governmental policy was to treat sleeping sickness in isolation camps. In general, incurable diseases were rarely admitted into overstretched medical facilities, while patients with conditions, which progressed extremely rapidly seemingly struggled to reach the hospital in time. Influenza, for example, which reportedly infected one-third of the global population in 1918-19, killing an estimated 10-20 per cent of those affected, also caused severe mortality in Uganda in $1919 .{ }^{70}$ Still, it seems clear that the Toro Hospital records underestimate the local severity of the pandemic. Forty patients with influenza were admitted in 1919, accounting for 13 per cent of all cases in that year, of whom 7.5 per cent died. Both the number of cases and the death rate seem low, suggesting that most victims of influenza never made it to hospital. Conditions that could be easily treated in the outpatient department, meanwhile, would also tend to be excluded from the in-patient registers. Nonetheless, given the rarity of in-patient records from this period, and the limitations of alternative sources relating to the nature of the patient in colonial-era Africa, these registers have the potential to add significantly to our understanding of mission medicine in the African past.

\section{Analysis}

The in-patient registers permit an analysis of trends in disease diagnosis, hospital death rates and ALOS in hospital between 1908 and 1970, thus providing new insights into changing patterns of mortality and morbidity through the colonial and early postcolonial eras. Table 2 presents the frequency of diagnosed disease categories over time. The most commonly diagnosed conditions over the entire period were skin diseases (12.0 per cent), STIs (10.6 per cent), respiratory (10.5 per cent), symptomatic (9.2 per cent), parasitic and infectious diseases (8.8 per cent) and malaria (8.4 per cent). What is more interesting than this overall ranking is how the relative significance of disease categories changed over time.

\footnotetext{
${ }^{68}$ The Mission Hospital, 29, 331, 1925, 177-78.

${ }^{69}$ A. H. D. Kilian, A. Langi, A. Talisuna and G. Kabagambe, 'Rainfall Pattern, El Niño and Malaria in Uganda', Transactions of The Royal Society of Tropical Medicine and Hygiene, 1999, 93, 1, 22-23. Given the very limited information available on labo-
}

ratory equipment and diagnostic tools over this period, conclusions drawn must be tentative.

${ }^{70} \mathrm{~K}$. David Patterson and Gerald F. Pyle, 'The Diffusion of Influenza in Sub-Saharan Africa During the 19181919 Pandemic', Social Science and Medicine, 1983, 17, 17, 1299-307. 
The most obvious change over the period studied relates to the sharp decline in skin diseases (mainly tropical ulcers), STIs and symptomatic diagnoses. These categories, which had been the most common between 1908 and 1919, ranked 11th, 19th and 9th, respectively, in 1964-70. Symptomatic diagnoses had remained extremely common through to the end of the 1940s. Their relative rarity in the mid-late 1960s is striking, and seems likely to reflect not only superior diagnostic capacity by this period, with the renovated hospital benefiting from electricity and a new laboratory, but also the local population's growing familiarity with biomedical concepts, following the intensification of public health information campaigns in the 1950s and 1960s. ${ }^{71}$ Skin diseases formed a disease category that responded particularly well to sulfa drugs, introduced in Uganda around 1940, and to penicillin, which became widely available in the early 1950 s. ${ }^{72}$ Skin diseases had peaked in the 1930s at 17.2 per cent of all cases, then dropped to 8.2 per cent in the 1940s and 2.4 per cent in the 1960s. As Toro Hospital's resident doctor observed in 1963, there were now 'hardly any tropical ulcers', in marked contrast to the not so distant past. ${ }^{73}$ By this time, most skin disease cases would have treatable as outpatients. The decline of STIs, in contrast, began far in advance of any effective treatment. After peaking at 20.1 per cent of all cases in the 1920s, they fell to 10.8 per cent in the 1930s, and 4.1 per cent in the 1940s, decades when the cure rate for indigenous patients in the region was almost zero. This pattern then, as will be discussed further, either indicates a remarkable shift in local sexual behaviour, changes in diagnostic practice or of course changing assumptions about what symptoms or conditions were worth a trip to hospital. The only category that experienced a substantial fall was that of injury, which fell from around 6 per cent of cases before 1930 to 2 per cent after 1940. Animal attacks became extremely rare, as wild game was increasingly confined to reserves, and interpersonal violence seemingly less destructive, as state authority restricted the carrying of weapons. $^{74}$

By the 1960s, the most common conditions were respiratory diseases, the subcategory gastroenteritis, infectious and parasitic diseases, the sub-category malaria and genitourinary diseases. The frequency of respiratory diseases had almost doubled since 1908-19, with most of the increase occurring after the 1940s. The trend in Toro mimicked that of Kampala, where pneumonia also became very common in the 1950s and 1960s, seemingly linked to increased exposure to infection, due to rising population density and mobility, increasing household size and a rapid expansion in schooling. ${ }^{75}$ The frequency of gastroenteritis had increased even more rapidly since the 1940s, from 2-4 per cent pre-1950 to 14.2 per cent between 1964 and 1970, with the vast majority of patients aged 0-14 years. It is likely that, as in Kampala, the rapid rise in diarrhoea and vomiting among young children was linked to the adoption of bottle-feeding in conditions where hygienic preparation and storage of formula was difficult. ${ }^{76}$ The rapid rise of $^{\circ}$

\footnotetext{
${ }^{71}$ Janet Goodall, 'The Hospital Care of East African Children', Journal of Tropical Paediatrics, 1972, 18, $1,48$.

${ }^{72}$ Ruanda Notes, 1963, 164, 6.

${ }^{73}$ Doyle, Before HIV, 307, 322.

${ }^{74}$ Tibamanya M. Mushanga, Criminal Homicide in Uganda (Kampala: LawAfrica, 2013), 57-58.
}

\section{A. Shaper and L. Shaper, 'Analysis of Medical} Admissions to Mulago Hospital, 1957', East African Medical Journal, 1958, 35, 12, 647-78.

${ }^{76}$ Nimrod O. Bwibo, 'Common Causes of Death in Children at Mulago Hospital, Kampala, Uganda', Clinical Pediatrics, 1970, 9, 11, 691-94; Derek 
infectious and parasitic diseases in the 1960s was due above all to measles, which seemingly had increased in both frequency and severity across East Africa since the 1950s. ${ }^{77}$ By the 1960s, infectious and parasitic diseases had become increasingly associated with childhood, as the average age of patients within this category fell to 14, compared with 21 years in the 1940s. This epidemiological shift was driven by measles, which rose from 3.5 per cent to 36 per cent of infectious and parasitic diseases over this period. Meanwhile, in the absence of bed nets, it is likely that the relative increase in malaria cases partly reflected a growing popular awareness that effective biomedical treatment for the disease existed and partly was the result of more precise diagnosis by medical staff. Toro Hospital employed a laboratory assistant when it reopened in 1964 and by 1971 was performing 13,000 laboratory tests per annum. ${ }^{78}$ It seems very likely that the decline in symptomatic diagnoses such as debility, fever and headache in the 1960s stemmed from them being categorised as signs of malaria. Similarly, the rise of genitourinary cases likely reflected medical recategorisation of symptoms, which previously were ascribed to STIs.

Given this improvement in diagnostic capacity, and the enhanced repertoire of medication available after 1950, it may seem surprising that treatment outcomes, shown in Figure 6, in 1964-70 were not strikingly superior to those of the earlier period. It may be that the fall in the proportion of patients who were pronounced 'cured' at discharge, and the accompanying rise in patients categorised as 'improved' or 'much improved', seen most clearly between 1908-19 and 1920-29, reflected personal classificatory convention to some degree. When compared with the 1940s, the 1964-70 period saw a sharp fall in the proportion of patients whose condition had deteriorated or remained unchanged and a smaller but still important rise in the overall death rate. Analysing the age-profile of deaths in hospital, this overall rise was driven by the doubling of the death rate among 0- to 14-year-olds to 7.8 per cent in the 1960s. Given the enormous expansion of demand for treatment, and the rapid increase in respiratory infections and gastroenteritis in the young, it is likely that more patients were being admitted in extremis in this decade, as was the case in Kampala. ${ }^{79}$ But the impressiveness of the outcomes in 1908-19 should not be ignored. For four in five patients to be pronounced cured, and only c. 6 per cent to have died, was a substantial achievement. It may be that medical missionaries' emphasis on hygiene and devoted nursing, dominant themes in their writings, was well-placed. ${ }^{80}$

While treatment outcomes provide a rather mixed picture, those relating to the ALOS, an indicator of medical efficiency, tell a remarkable story of sustained rapid reduction, from the hospital's first decade of existence. ${ }^{81}$ Figure 7 compares ALOS for Toro inpatients with those at Uganda's government hospitals. Between 1908 and 1970, Toro patients' ALOS declined almost lineally $\left(R^{2}=0.90\right)$, from close to 1 month ( 28 days) in

Jelliffe, 'Pediatrics in Uganda', Clin. Pediat., 1965, 4, $1,55-61$.

${ }^{77}$ lliffe, Doctors, 132. It is possible of course that parents had not considered measles to be a condition suitable for hospital treatment before the 1950s.
${ }^{78}$ Rwenzori Diocese: Correspondences Minutes \& Reports, 1971, Archbishop of Uganda, 92/1, Archives of the Church of Uganda Online.

${ }^{79}$ Bwibo, 'Common', 691-94.

${ }^{80}$ Mercy and Truth, 1905, 9, 97, 16-20; The Mission Hospital, 1928, 32, 360, 14

${ }^{81}$ OECD 2015, 108. 


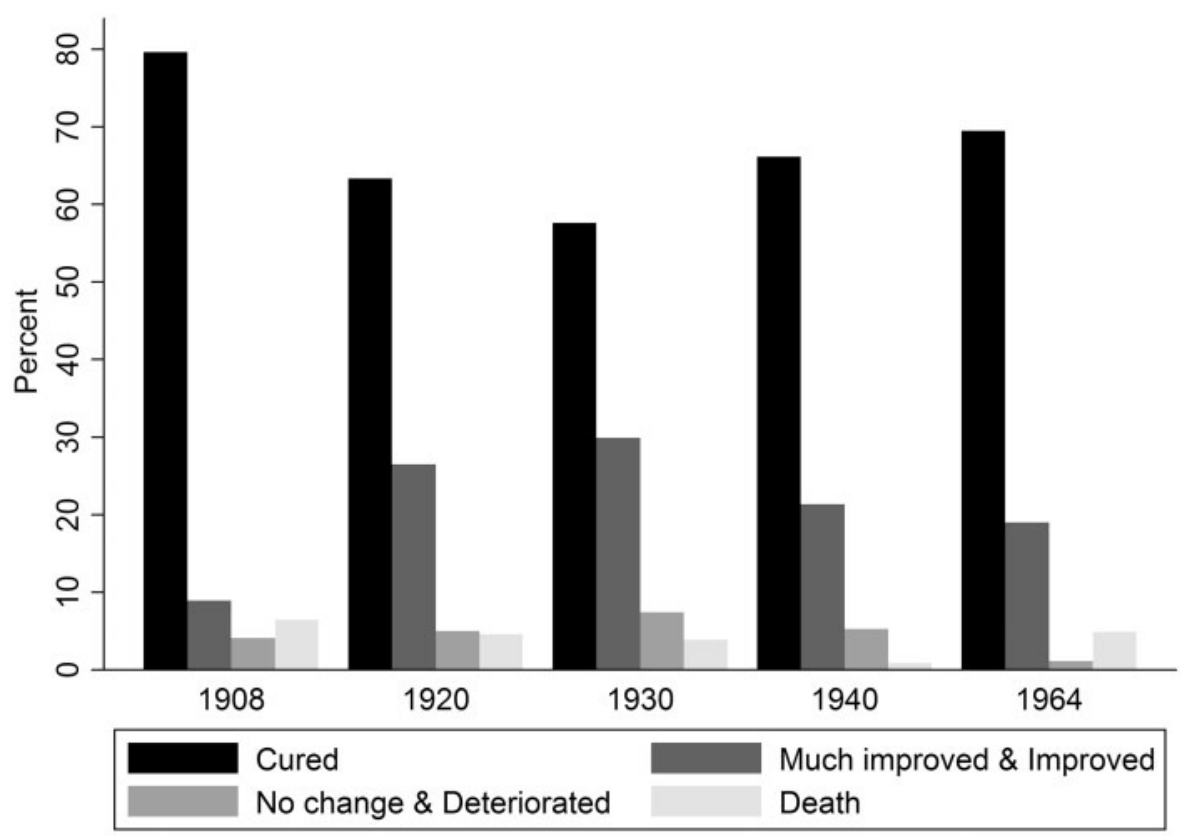

Fig. 6. Medical treatment outcomes, 1908-49.

the late 1900s to just 2 weeks (15 days) at the end of the 1930s and to less than 1 week (6 days) in the 1960s. This was a pattern seen also in Ugandan government hospitals and in global trends. Its major significance is that it enabled Toro Hospital and the Ugandan medical system more generally, to provide in-patient care for a substantially larger number of patients without a proportionate increase in the numbers of beds or medical staff (Toro's bed capacity peaked in 1929). This steady rise in efficiency and throughput provides crucial context for evaluating the outcomes data. Maintaining or slightly improving levels of treatment while experiencing rising pressure of numbers was a major achievement. This reduction in patient length of stay was driven by shifts in both therapeutic capacity and norms of best practice. It seems likely that the pronounced dips in ALOS in the 1930 s and 1950s were related to the introduction of sulfonamide and penicillin in those decades, which meant that bacterial infections such as tropical ulcer and syphilis no longer required weeks of intensive nursing. ALOS for skin diseases and STIs fell from more than 30 days at the start of the century to 7 days in the 1960s (see Table 2). For a range of other conditions, such as cardiac and circulatory, recognition of the dangers of extended bed rest prompted early discharge before full recovery, a change that would have reduced overall cure rates.

These overall trends offer significant insights into the distinctive nature of epidemiological transition and medical provision in this part of East Africa over the early and middle decades of the 20th century. The unique value of the micro-data, however, relates to their potential to reveal variation in experience not only by age and sex but also by 


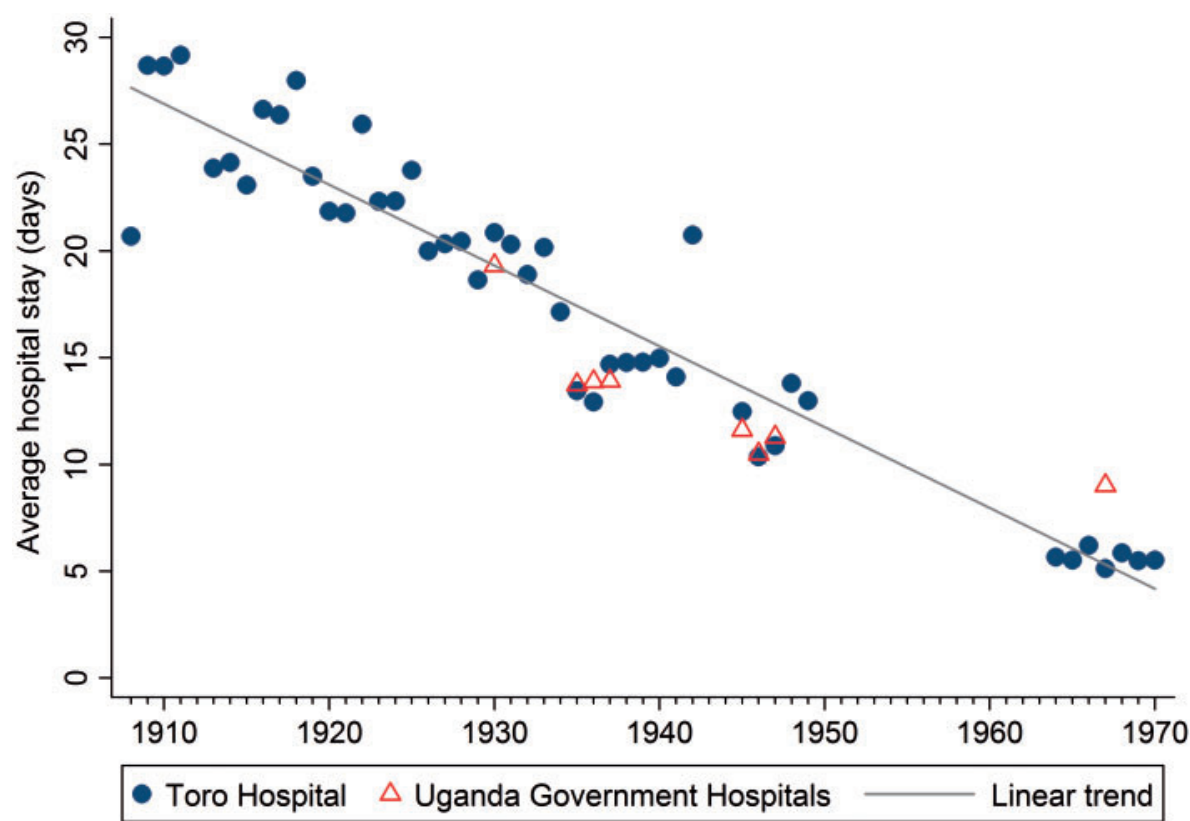

Fig. 7. Average length of hospital stay, 1908-70. Linear trend line: $R^{2}=0.90$. Sources: ALOS at Ugandan government hospitals derived from Uganda Protectorate, Annual Report of the Medical Department, Entebbe (1931-47).

(i) travel distance, (ii) numeracy and (iii) religion. In the following in-depth analysis, we apply basic multivariate regression analyses (Tables 3-6) so that various confounding factors, such as patients' characteristics, local monthly rainfall and temperature, which might be driving correlations, can be controlled for. ${ }^{82}$

\section{Travel Distance}

We geocoded patients' residence locations in Figure 5, which enabled us to compute their distance travelled to Toro Hospital. Online Appendix Figure A2 shows in-patients' average travel distance over time and Online Appendix Figure A3 maps each in-patient's residence location. With the average patient living $20.4 \mathrm{~km}$ away from the hospital between 1908 and 1949, and most people having to travel on foot, distance was clearly a significant factor affecting patient treatment choices and potentially the diseases to which they were exposed to. During this period, men travelled almost $4 \mathrm{~km}$ further to the hospital than women, and adults travelled $6.5 \mathrm{~km}$ further than children (see Table A1 in Online Appendix). This reflected not only variation in physical strength but also individual freedom to travel and to be absent from home for prolonged

${ }^{82}$ Rainfall data drawn from Michiel De Haas and Kostadis Papaioannou, 'Resource Endowments and Agricultural Commercialization in Colonial Africa', EHES Working Paper 2017, 111. Average monthly temperature retrieved through World Bank Climate Change Knowledge Portal (accessed 10 November 2017). 
periods. $^{83}$ Less predictably perhaps, religion was also associated with distance. Muslims were the most urban of all patient categories, living $8.2 \mathrm{~km}$ closer to Fort Portal on average than followers of traditional religion (the reference group). This may have been influenced by the political marginalisation of Islam in colonial Uganda, which limited economic opportunities for most Muslims to town-based activities (e.g. butchery, petty trade and transport). Anglican patients lived on average about $7 \mathrm{~km}$ closer to Fort Portal than people following traditional religion, demonstrating how Protestantism radiated from the mission centre, and perhaps reflecting Anglicans' privileged position in terms of employment not only within the institutions of the Church but also within colonial and chiefly administrations. ${ }^{84}$

Patients' distance from the hospital varied significantly by disease category. Unsurprisingly, maternity was most localised, but even here, patients travelled an average distance of $13 \mathrm{~km}$, providing further evidence of the substantial reach of the hospital. Other conditions, where patients were relatively local, included gastroenteritis and respiratory infections, suggesting that distance was somewhat inversely related to the urgency of a patient's condition. Chronic or longer-term health problems such as STIs, nervous conditions and cancer were those where patients travelled furthest. Distance influenced not only patient choice but also their experience within the hospital. The further patients had to travel, the longer they would stay and the lower the likelihood they would improve, be cured or survive. It seems probable that the material and opportunity costs of travel deterred patients with chronic conditions from seeking treatment until their condition was relatively advanced.

Whether the geographical distribution of patients was a proxy for education and religion will be considered in the following two sections.

\section{Numeracy}

Education has been repeatedly demonstrated to be associated with lower levels of morbidity and mortality in Africa. ${ }^{85}$ Toro Hospital's registers did not record patients' levels of educational attainment directly nor did they provide an indication of literacy levels by recording patients' signatures. They did, however, note patients' self-reported ages, which permits calculations of age-heaping, that is, the tendency to report one's own age as rounded numbers such as 0 and 5, a standard proxy of numeracy. Indeed, Figure 4 shows considerable age-heaping on those digits. The extent of age-heaping for a given population can be established by the Whipple's Index, ${ }^{86}$ the ratio of the observed frequency of ages ending in 0 or 5 to the frequency predicted by assuming a uniform distribution of

${ }^{83}$ Melvin Perlman, 'The Changing Status and Role of Women in Toro (Western Uganda)', Cahiers d'études africaines, 1966, 6, 24, 564-91.

${ }^{84}$ Felix Meier zu Selhausen, Marco H. D. van Leeuwen and Jacob Weisdorf, 'Social Mobility among Christian Africans: Evidence from Anglican Marriage Registers in Uganda, 1895-2011' Economic History Review, 2018, 71, 4, 1291-321. It should be acknowledged that Muslims in western Uganda were believed to be a largely urban community, reflecting their prominence in trade and butchery; Anglicans are also likely to have clustered around major missions such as Fort Portal.

${ }^{85}$ Jack Caldwell, 'Education as a Factor in Mortality Decline: An Examination of Nigerian Data', Population Studies, 1979, 33, 3, 395-413; John Cleland and Jerome van Ginneken, 'Maternal Education and Child Survival in Developing Countries: The Search for Pathways of Influence', SSM, 27, 12, 1988, 1357-68.

${ }^{86}$ Henry Shyrock and Jacob Siegel, The Methods and Materials of Demography (Washington D.C.: U.S. Bureau of the Census, 1973), 201-51. 


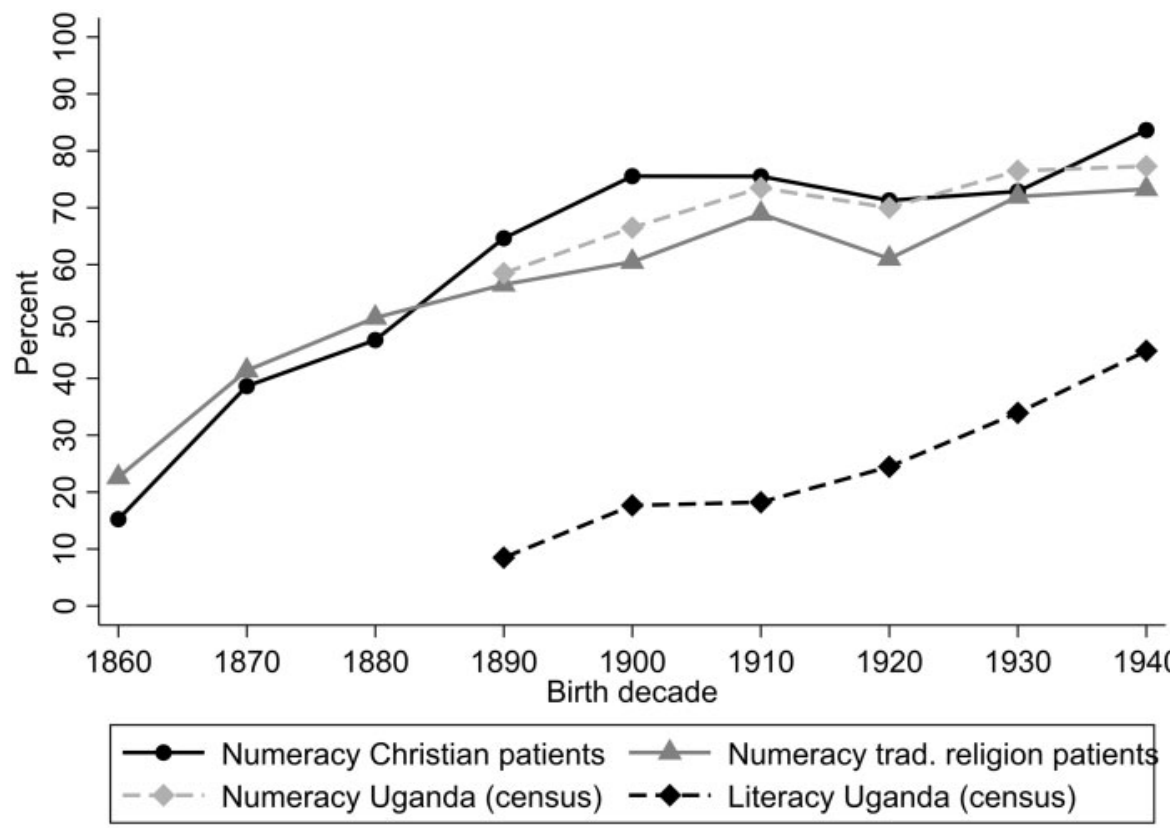

Fig. 8. Numeracy (ABCC index) of Toro patients by religion and numeracy/literacy in Uganda. Decadal sample sizes $<50$ excluded.

Sources: Literacy estimates of total Uganda population based on 1991 and 2002 Uganda censuses including population aged 23-72 years. UBOS (Uganda Bureau of Statistics), Population and Housing Census 1991, Kampala, 1991. UBOS (Uganda Bureau of Statistics), Population and Housing Census 2002, Kampala, 2002. Basic numeracy (ABCC index) estimates of the Uganda population based on 1991 Uganda census.UBOS (Uganda Bureau of Statistics), Population and Housing Census 1991 (Kampala, 1991).UBOS (Uganda Bureau of Statistics), Population and Housing Census 2002 (Kampala, 2002).UBOS (Uganda Bureau of Statistics), Population and Housing Census 1991 (Kampala, 1991).UBOS (Uganda Bureau of Statistics), Population and Housing Census 2002 (Kampala 2002).

terminal digits. The ABCC Index, a linear transformation of the Whipple's Index, represents the share of the population able to report their own age exactly, ranging between 0 and $100 .{ }^{87}$ Figure 8 compares the $A B C C$ indices of patients of Christian and traditional faith and the general Ugandan population by birth cohort. It seems reasonable to hypothesise that numeracy, the basic ability to count and complete simple calculations, could serve as a proxy for basic education in colonial Africa, ${ }^{88}$ and certainly, it could be expected that numerate individuals would be well-equipped to effectively engage with

${ }^{87}$ Brian A'Hearn, Jörg Baten and Dorothee Crayen, 'Quantifying Quantitative Literacy: Age Heaping and the History of Human Capital', Journal of Economic History, 2009, 69, 3, 783-808.

${ }^{88} \mathrm{Cf}$. Jörg Baten and Johan Fourie, 'Numeracy of Africans, Asians, and Europeans During the Early Modern Period: New Evidence from Cape Colony Court Registers', Economic History Review, 2015, 68, 632-56; Felix Meier zu Selhausen and Jacob
Weisdorf, 'A Colonial Legacy of African Gender Inequality? Evidence from Christian Kampala, 18952011', Economic History Review, 2016, 69, 1, 22957; Gabriele Cappelli and Jörg Baten, 'European Trade, Colonialism, and Human Capital Accumulation in Senegal, Gambia and Western Mali, 1770-1900', Journal of Economic History, 2017, 77, 3, 920-51. 
Table 3. Length of hospital stay (days) and treatment outcomes by religion, 1908-49

\begin{tabular}{|c|c|c|c|}
\hline & $\begin{array}{l}\text { Length } \\
\text { (OLS) }\end{array}$ & $\begin{array}{l}\text { Cured } \\
\text { (Probit) }\end{array}$ & $\begin{array}{l}\text { Death } \\
\text { (Probit) }\end{array}$ \\
\hline Male & $\begin{array}{l}2.113^{* * *} \\
(0.415)\end{array}$ & $\begin{array}{c}0.013 \\
(0.010)\end{array}$ & $\begin{array}{c}0.004 \\
(0.004)\end{array}$ \\
\hline Age (years) & $\begin{array}{l}0.178 * * * \\
(0.013)\end{array}$ & $\begin{array}{c}-0.002 * * * \\
(0.000)\end{array}$ & $\begin{array}{c}0.000 \\
(0.000)\end{array}$ \\
\hline Numerate & $\begin{array}{l}0.952 * * \\
(0.463)\end{array}$ & $\begin{array}{r}-0.000 \\
(0.010)\end{array}$ & $\begin{array}{r}-0.005 \\
(0.004)\end{array}$ \\
\hline Anglican & $\begin{array}{c}-1.731 * * * \\
(0.467)\end{array}$ & $\begin{array}{l}0.066^{* * *} \\
(0.005)\end{array}$ & $\begin{array}{c}-0.014 * * * \\
(0.004)\end{array}$ \\
\hline Catholic & $\begin{array}{r}-0.077 \\
(0.583)\end{array}$ & $\begin{array}{r}-0.000 \\
(0.013)\end{array}$ & $\begin{array}{r}-0.000 \\
(0.005)\end{array}$ \\
\hline Muslim & $\begin{array}{c}-4.098 * * * \\
(0.878)\end{array}$ & $\begin{array}{r}-0.011 \\
(0.026)\end{array}$ & $\begin{array}{c}0.005 \\
(0.010)\end{array}$ \\
\hline African trad. religion & ref. & ref. & ref. \\
\hline Patients per year & $\begin{array}{c}0.001 \\
(0.003)\end{array}$ & $\begin{array}{c}0.000 \\
(0.000)\end{array}$ & $\begin{array}{c}-0.000 * \\
(0.000)\end{array}$ \\
\hline Distance (In) & $\begin{array}{l}1.034^{* * *} \\
(0.107)\end{array}$ & $\begin{array}{c}-0.013 * * * \\
(0.002)\end{array}$ & $\begin{array}{c}0.000 \\
(0.001)\end{array}$ \\
\hline Rainfall (In) & $\begin{array}{c}-0.276 \\
(0.107)\end{array}$ & $\begin{array}{c}0.005 \\
(0.005)\end{array}$ & $\begin{array}{c}-0.004^{* *} \\
(0.002)\end{array}$ \\
\hline Temperature & $\begin{array}{l}1.138^{* * *} \\
(0.392)\end{array}$ & $\begin{array}{c}0.007 \\
(0.009)\end{array}$ & $\begin{array}{r}-0.001 \\
(0.004)\end{array}$ \\
\hline Year FE & Yes & Yes & Yes \\
\hline Disease category FE & Yes & Yes & Yes \\
\hline Observations & 12,186 & 12,621 & 10,863 \\
\hline (Pseudo) $R^{2}$ & 0.153 & 0.192 & 0.067 \\
\hline
\end{tabular}

Notes: Robust standard errors in parentheses clustered at patient level. Robust standard errors clustered at the individual level in parentheses. Results are robust to including doctor fixed effects. $* * *, * *$, *Estimate significance at 0.01, 0.05, 0.10 levels, respectively.

the notions of time and quantification on which effective biomedical treatment depended. In fact, while overall age-heaping was significant in the registers, there was no significant variation in cure and death rates or distribution of disease between individuals who did not age-heap and those who did (see Table 3). It is also noteworthy that there was almost no variation in levels of age-heaping between Christians and followers of African traditional religion born 1860-1940.

Given that Christian missions in this era held a virtual monopoly on formal education in western Uganda, ${ }^{89}$ and missionaries regarded schooling as a particularly successful route to conversion, this is surprising. No doubt, some children went to mission schools and never converted, but it seems necessary to consider other mechanisms, which enabled the $A B C C$ index for followers of traditional religion to increase from 15 per cent for people born in the 1860s to 73 per cent for those born in the 1930s. There were in fact a range of colonial innovations that required people to adopt a precise age. Census-taking 
required age estimation; birth registration was a legal requirement, albeit not universally practised; local government imposed a minimum marriage age and men had to pay tax from 18 years of age. These findings support previous research, which found that substantial variation in health outcomes required more than minimal educational attainment, $^{90}$ and suggest that some caution is required in interpreting the relationship between numeracy indices and human capital formation and transfer in colonial Africa. As Figure 8 charts, both census-based numeracy and literacy skills for the whole of Uganda increased at the same rate and indeed at a similar rate to Toro Hospital's ABCC index, but literacy levels, a superior guide to educational attainment, were always around 40 per cent points lower.

\section{Religion}

Mission schools and churches sought not only to convert Africans to new religious beliefs but also to transform adherents' behaviour, family life and interpersonal relations. New forms of clothing and housing were often held up as physical demonstrations of commitment to the new faith. Western female missionaries and locally trained midwives taught women novel techniques of pre-natal care, childbirth and child-rearing, with the goal of creating a new generation whose worldview and habits were shaped by not only Christianity but also biomedical principles of hygiene and nutrition. ${ }^{91}$ Mission intentions are clear, but to what extent did the moral and formal educational aspects of Christian conversion affect African health behaviour?

Some recent scholarship on the long-term impact of historical missionary activities on contemporary African health suggests that early missionary investment has had a significant legacy. Among regions historically close to European-run mission stations, proximity to a mission that also provided healthcare has been found to be associated with lower HIV prevalence nowadays. ${ }^{92}$ Other studies have indicated that Islam too is associated with lower levels of HIV, although the significance of Islam is reduced once circumcision is accounted for. ${ }^{93}$ The suggestion that Christianity reduces the prevalence of HIV has been disputed meanwhile, in part because of discordance between actual and reported behaviour. ${ }^{94}$ Our data, meanwhile, are able to shed light on the influence of religion on other categories of disease where effects might be expected.

The multivariate regression in Table 3 shows religion did impact significantly on patients' experience in hospital. Anglicans were statistically more likely to be cured and less likely to die than followers of all other religions. They also stayed in hospital for shorter periods (c. 2 days) than patients of traditional religion. These positive outcomes may indicate better understanding of biomedicine, so that Anglicans came to hospital

${ }^{90}$ Cleland and van Ginneken, 'Maternal', 1359.

${ }^{91}$ Comaroff and Comaroff, Revelation, 66; Vaughan, Curing, 66.

${ }^{92} J u l i a$ Cagé and Valeria Rueda, 'Sex and the Mission: The conflicting effects of early Christian missionson HIV in sub-Saharan Africa', Unpublished manuscript University of Oxford, 2018. See also Federico Mantovanelli, 'Christian Missions, HIV, and Sexual Behaviors in sub-Saharan Africa,' Technical Report, Boston College 2016.
${ }^{93}$ Peter B. Gray, 'HIV and Islam: Is HIV Prevalence Lower among Muslims?', SSM, 2004, 58, 9, 175156.

${ }^{94}$ Baffour K. Takyi, 'Religion and Women's Health in Ghana: Insights into HIV/AIDs Preventive and Protective Behavior', SSM, 2003, 56, 6, 1221-34; J. Trinitapoli, 'Religious Teachings and Influences on the ABCS of HIV Prevention in Malawi', SSM, 2009, 69, 2, 199-209. 


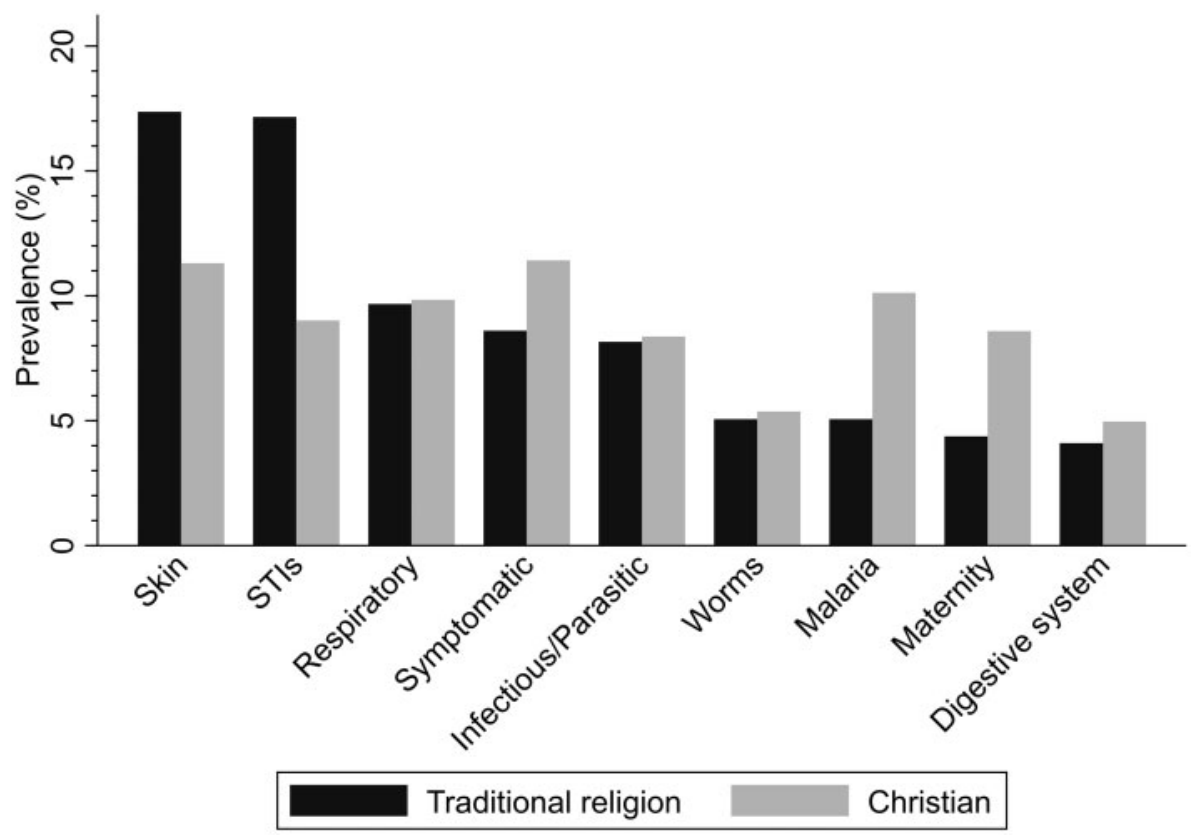

Fig. 9. Prevalence of diseases by religious belief, 1908-49. Diseases shown with prevalence $>5$ per cent.

with less advanced conditions and responded more positively to treatment. Alternatively, they may reflect Anglicans' superior socio-economic status in Toro, with Protestants predominating among the chiefly landowning class and state employees. ${ }^{95}$ Muslims left the hospital even more quickly than Anglicans but were no more likely to survive or be cured than adherents of traditional religion. Rather than proximity to the hospital facilitating Muslims' early departure, it seems more likely this resulted from a desire to escape intensive proselytisation.

Figure 9 shows that religion also affected the distribution of disease among Toro Hospital's patients. Unsurprisingly, Christians were statistically much more likely to give birth in hospital than followers of traditional religion. That they were also twice as likely to be admitted with malaria is less easily explained. Practicable preventive measures were unavailable in this period, so we can hypothesise that, as Christians were more mobile, they were more likely to be infected in higher prevalence areas and that they were more likely to recognise the symptoms of severe malaria and so attend the hospital. ${ }^{96}$ That Christians were more likely to be admitted with a symptomatic diagnosis can be interpreted more as a sign of faith in, rather than knowledge of, biomedicine.

One group of diseases where religious variation would be expected were those potentially influenced by hygienic practices. It is then surprising that, of patients who were admitted, Christians were significantly more likely to be diagnosed with worms than

\footnotetext{
${ }^{95}$ Meier zu Selhausen, van Leeuwen and Weisdorf, ${ }^{96}$ Derek Peterson, Ethnic Patriotism and the East 'Social Mobility', 1295-6. 
Table 4. Determinants of worm diagnosis, 1908-49

\begin{tabular}{|c|c|c|c|c|}
\hline & $\begin{array}{c}\text { All ages } \\
\text { (1) }\end{array}$ & $\begin{array}{c}\text { All ages } \\
(2)\end{array}$ & $\begin{array}{c}\text { Adults } \\
\text { (3) }\end{array}$ & $\begin{array}{l}\text { Children } \\
\text { (4) }\end{array}$ \\
\hline Male & $\begin{array}{c}-0.008 * * \\
(0.003)\end{array}$ & $\begin{array}{c}-0.007 * * \\
(0.004)\end{array}$ & $\begin{array}{c}-0.011 * * * \\
(0.004)\end{array}$ & $\begin{array}{r}-0.000 \\
(0.008)\end{array}$ \\
\hline Age (years) & $\begin{array}{c}-0.000 * * * \\
(0.000)\end{array}$ & $\begin{array}{c}-0.000 * * * \\
(0.000)\end{array}$ & $\begin{array}{l}0.000 * * \\
(0.000)\end{array}$ & $\begin{array}{r}-0.001 \\
(0.001)\end{array}$ \\
\hline Numerate & $\begin{array}{l}0.005^{* *} \\
(0.004)\end{array}$ & $\begin{array}{l}0.013^{* *} \\
(0.006)\end{array}$ & $\begin{array}{c}0.003 \\
(0.004)\end{array}$ & \\
\hline Anglican & $\begin{array}{c}-0.007 * * \\
(0.004)\end{array}$ & $\begin{array}{r}-0.006 \\
(0.004)\end{array}$ & $\begin{array}{r}-0.004 \\
(0.004)\end{array}$ & $\begin{array}{c}-0.007 \\
(0.010)\end{array}$ \\
\hline Catholic & $\begin{array}{c}0.006 \\
(0.005)\end{array}$ & $\begin{array}{c}0.007 * \\
(0.007)\end{array}$ & $\begin{array}{c}0.000 \\
(0.006)\end{array}$ & $\begin{array}{l}0.027 * * \\
(0.012)\end{array}$ \\
\hline Muslim & $\begin{array}{c}-0.022 * * * \\
(0.006)\end{array}$ & $\begin{array}{c}-0.023 * * * \\
(0.006)\end{array}$ & $\begin{array}{c}-0.020 * * * \\
(0.006)\end{array}$ & $\begin{array}{r}-0.025 \\
(0.019)\end{array}$ \\
\hline African trad. religion & ref. & ref. & ref. & ref. \\
\hline Patients per year & $\begin{array}{r}-0.000 \\
(0.000)\end{array}$ & $\begin{array}{r}-0.000 \\
(0.000)\end{array}$ & $\begin{array}{r}-0.000 \\
(0.000)\end{array}$ & $\begin{array}{c}-0.000 * * \\
(0.000)\end{array}$ \\
\hline Distance (In) & & $\begin{array}{c}0.001 \\
(0.000)\end{array}$ & $\begin{array}{c}0.001 \\
(0.001)\end{array}$ & $\begin{array}{c}0.001 \\
(0.002)\end{array}$ \\
\hline Year FE & Yes & Yes & Yes & Yes \\
\hline Observations & 14,033 & 12,377 & 7,674 & 4,101 \\
\hline Pseudo $R^{2}$ & 0.099 & 0.093 & 0.117 & 0.059 \\
\hline
\end{tabular}

Notes: Robust standard errors in parentheses clustered at patient level. Robust standard errors clustered at the individual level in parentheses. Results are robust to including doctor fixed effects. $* * *, * *$, *Estimate significance at 0.01, 0.05, 0.10 levels, respectively.

followers of traditional religion (see Table 4). In contrast, diagnosis of worms among Muslims was significantly lower than average, perhaps reflecting their religion's emphasis on ritual cleanliness. The implication of this is that principles of hygiene may have featured more fully in Christian teaching than in adherents' practice.

Not all skin diseases were affected by hygiene, but the dominant form in early colonial Toro, tropical ulcer, was to a degree. Tropical ulcer typically developed from inadequate cleansing of a minor wound. Exposure to soil and stagnant water and risk of suffering minor wounds on the foot or lower leg, though, were both associated with agricultural labour, ${ }^{97}$ so it is possible that the lower frequency of skin diseases among Christians' (see Table 5) was partly a reflection of variation in employment, as well as personal cleanliness. Differential admission perhaps also reflected missionising strategy. Megan Vaughan has suggested that 'heathens' were more likely to be admitted with tropical ulcer because their lengthy treatment afforded opportunities for intensive Christian instruction. ${ }^{98}$ Tropical ulcer in Toro Hospital did have a particularly long ALOS before the 1940s, 
Table 5. Determinants of ulcer-diagnosis, 1908-49

\begin{tabular}{|c|c|c|c|c|}
\hline & $\begin{array}{c}\text { All ages } \\
\text { (1) }\end{array}$ & $\begin{array}{c}\text { All ages } \\
(2)\end{array}$ & $\begin{array}{c}\text { Adults (15+years) } \\
\text { (3) }\end{array}$ & $\begin{array}{c}\text { Children (0-14 years) } \\
\text { (4) }\end{array}$ \\
\hline \multirow[t]{2}{*}{ Male } & $0.026 * * *$ & $0.022 * * *$ & $0.024^{* * *}$ & 0.008 \\
\hline & $(0.005)$ & $(0.005)$ & $(0.006)$ & $(0.007)$ \\
\hline \multirow[t]{2}{*}{ Age (years) } & $0.000 *$ & 0.000 & $-0.001 * * *$ & $-0.011 * * *$ \\
\hline & $(0.000)$ & $(0.000)$ & $(0.000)$ & $(0.001)$ \\
\hline \multirow[t]{2}{*}{ Numerate } & $0.013 * *$ & $0.009 *$ & 0.000 & \\
\hline & $(0.006)$ & $(0.006)$ & $(0.006)$ & \\
\hline \multirow[t]{2}{*}{ Anglican } & $-0.051 * * *$ & $-0.043 * * *$ & $-0.060 * * \star$ & $-0.041 * * *$ \\
\hline & $(0.005)$ & $(0.005)$ & $(0.007)$ & $(0.008)$ \\
\hline \multirow[t]{2}{*}{ Catholic } & $-0.011 *$ & -0.006 & $-0.018 * *$ & -0.006 \\
\hline & $(0.006)$ & $(0.007)$ & $(0.008)$ & $(0.010)$ \\
\hline \multirow[t]{2}{*}{ Muslim } & $-0.043 * * *$ & $-0.033^{* * *}$ & $-0.042 * \star *$ & -0.009 \\
\hline & $(0.009)$ & $(0.010)$ & $(0.011)$ & $(0.020)$ \\
\hline African trad. religion & ref. & ref. & ref. & ref. \\
\hline \multirow[t]{2}{*}{ Patients per year } & 0.000 & 0.000 & -0.000 & -0.000 \\
\hline & $(0.000)$ & $(0.000)$ & $(0.000)$ & $(0.000)$ \\
\hline \multirow[t]{2}{*}{ Distance (ln) } & & $0.011 * * *$ & $0.012 * * *$ & $0.010 * * *$ \\
\hline & & $(0.001)$ & $(0.002)$ & $(0.002)$ \\
\hline \multirow[t]{2}{*}{ Bwamba County } & & 0.017 & -0.003 & $0.075^{* *}$ \\
\hline & & $(0.016)$ & $(0.016)$ & $(0.042)$ \\
\hline \multirow[t]{2}{*}{ Rainfall (In) } & 0.012 & 0.002 & 0.000 & 0.004 \\
\hline & $(0.003)$ & $(0.003)$ & $(0.003)$ & $(0.004)$ \\
\hline \multirow[t]{2}{*}{ Temperature } & $0.008^{*}$ & $0.012^{* *}$ & $0.015^{* *}$ & 0.004 \\
\hline & $(0.005)$ & $(0.005)$ & $(0.006)$ & $(0.007)$ \\
\hline Year FE & Yes & Yes & Yes & Yes \\
\hline Observations & 14,497 & 12,859 & 8,569 & 4,247 \\
\hline Pseudo $R^{2}$ & 0.043 & 0.055 & 0.066 & 0.147 \\
\hline
\end{tabular}

Notes: Robust standard errors in parentheses clustered at patient-level. Robust standard errors clustered at the individual level in parentheses. Results are robust to including doctor fixed effects. $* * *, * *$, *Estimate significance at 0.01, 0.05, 0.10 levels, respectively.

peaking at 36 days in 1908-29 (see Table 2). The implication then is that in relation to skin diseases, Christianity may have shaped hospital incidence through its influence on exposure, self-treatment and admission strategy.

As Figure 9 shows, STls formed the group of diseases whose diagnosis among followers of African traditional religion was highest, when compared to Christians. Taken at face value, this result seems to reinforce missionary claims about the transformative moral impact of conversion to Christianity. Albert Cook's assertion in 1908 that 'Christianity from the beginning has acted as a deterring and restraining force, and is indeed when intelligently accepted, the only true prophylaxis to this terrible scourge' was typical in its conviction that the wholehearted adoption of Christian values was the only route to sexual morality. ${ }^{99}$ In part, this reflected a perception common among European

\footnotetext{
${ }^{99}$ Albert Cook, 'Syphilis in the Uganda Protectorate', British Medical Journal, 1908, 12, 2, 1780-81.
} 
observers in Uganda that indigenous codes governing sexuality had weakened, that traditional cultures were too rigid and fragile to adapt to the rapid changes in gender, generational and chief-subject relationships that were an inevitable consequence of colonisation. This perspective was, of course, not unique to Uganda. Across the colonised world, Europeans repeated narratives of social collapse, where devastating epidemics of STIs were identified and represented as being fuelled by marital breakdown, alcoholism and monetisation. ${ }^{100}$ Morality and illness were seen to be inextricably interwoven. Selfidentification as Christian, however, did not in itself provide effective prophylaxis. As missionaries were all too aware, many, perhaps most, converts failed to adhere to expected standards of sexual behaviour. Their publications made much of those 'truly Christian households', where monogamously married couples instilled Christian family values in their children. But their internal communications bemoaned the tokenism of many converts and the backsliding of the once devout. ${ }^{101}$ The history of early Christianity in Uganda is on one level a story of rapid, steady expansion, but in reality, the Christian mission was mobilised by a recurring sense of crisis, a cyclical need to cleanse the stables. From the first syphilis scare of 1907-08, through Albert and Katherine Cook's Social Purity campaign of 1921, the subsequent establishment of maternity centres across the country in the 1920s, designed to act as 'beacons of light', the Balokole Revival that started in 1929 and repeated attempts to maintain the sanctity and primacy of Christian marriage, which lasted through to the 1960s, this period was one where tensions around sexual behaviour characterised Christianity. ${ }^{102}$ It is striking that by the 1950 s, 87 per cent of male Christians in Buganda had been excommunicated, primarily for offences relating to sex (e.g. polygamy). ${ }^{103}$ Interpreting STI incidence data from a mission hospital in this era then must be done with some caution. Institutional and life histories indicate that Christian conversion resulted in absolute sexual probity for some, but not all; that some missionaries were more preoccupied by STIs than others and that fixation with sexuality ebbed and flowed. ${ }^{104}$ It would not be surprising if this context influenced patterns of diagnosis within Toro Hospital.

In some respects, the STI results, presented in Table 6, fit closely to expected outcomes. Men appear much more often as in-patients with STI diagnoses than women in the regression analysis. In Kampala, where similar patterns were observed in the late colonial period, the preponderance of male patients was not only explained partly by physiological reasons but also by reference to the assumed frequency with which local men paid for sex. ${ }^{105}$ The small town of Fort Portal and its rural hinterland would, of course, have generated very different forms of sexual networks and potentially, a sexual culture where female embarrassment or ignorance around STIs strongly influenced treatment-seeking behaviours. Even less surprisingly, STI diagnosis among adults was much higher than

${ }^{100}$ Hardiman, 'Introduction', 43-44; Francis J. Lambkin, 'An Outbreak of Syphilis on Virgin Soil', The Lancet, 1908, 1022.

${ }^{101}$ Elizabeth Dimock, Women, Mission and Church in Uganda: Ethnographic Encounters in an Age of Imperialism, 1895-1960s (London: Routledge, 2017), 78.
${ }^{102}$ Lambkin, 'Outbreak'; Albert Cook, Uganda Memories, 1897-1940 (Kampala: Uganda Society, 1945), 342.

${ }^{103}$ John Taylor, The Growth of the Church in Buganda (London: SCM, 1958), 182, 244.

${ }^{104}$ Peterson, Ethnic, 97-101; Doyle, Before HIV, 251.

${ }^{105}$ Aaron Masawe, 'Syphilis in Uganda' (MMed thesis, Makerere University, 1971). 


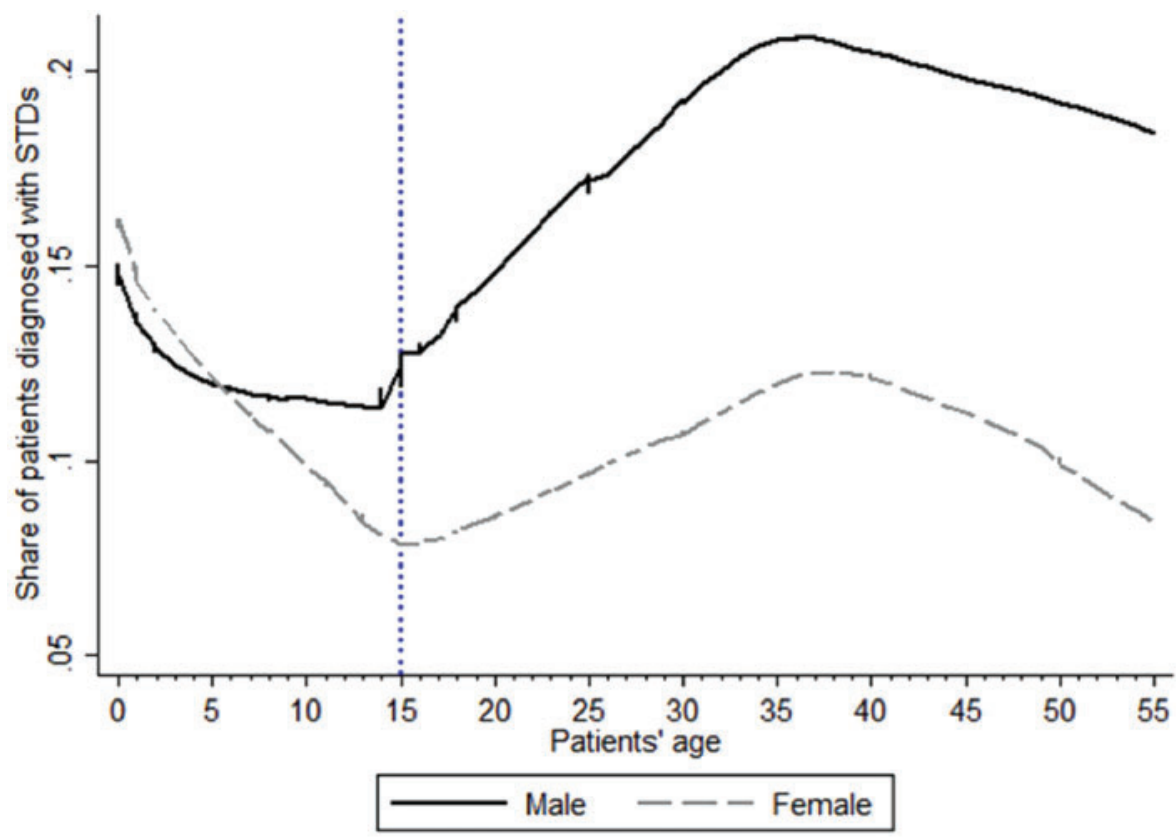

Fig. 10. STls by age and sex, 1908-49. Dotted vertical line marks break in diagnosis tend.

among children (0-14 years of age) in Toro Hospital. As Figure 10 shows, the broad pattern of hospital incidence by age and sex fits with standard expectations, with a decline from infancy to a very low level at age 14, then a steady rise to a second peak among people aged in their late 30s and then a gradual decline. However, that 16 per cent of infants were diagnosed with an STI (i.e. congenital syphilis) seems disproportionate, given that adult female incidence among in-patients peaked at 12 per cent, and even among men never exceeded 22 per cent. That a mother would transmit her infection in utero, or during childbirth or breastfeeding, was far from inevitable and if it did occur would have often resulted in miscarriage, stillbirth or neonatal mortality, rather than hospitalisation. Suspicions are further raised by the much higher frequency of diagnosis among boys than girls, after infancy. Figure 10 shows that between the ages of 3 and 14 years, STIs consistently accounted for 12-13 per cent of all admissions for boys, whereas STIs' share of diagnoses among girls fell steadily from infancy down to 7 per cent at the age of 15 years. Given that girls and boys appear in almost equal numbers in the registers, this variation cannot be explained by parents prioritising male children's health. It seems most likely to reflect medical overdiagnosis, with rashes and sores around the genital area being more visible in male children. As late as the 1940s, newly arrived, highly skilled doctors were shocked at how frequently CMS medical staff diagnosed syphilis among children in central Uganda. ${ }^{106}$ Subsequent research has emphasised that other

${ }^{106} \mathrm{H}$. Welbourn, 'First Impressions' (unpublished TS, 1946), 4-5. 
Table 6. Determinants of STI diagnosis, 1908-49

\begin{tabular}{|c|c|c|c|c|}
\hline & $\begin{array}{l}\text { All ages } \\
\text { (1) }\end{array}$ & $\begin{array}{c}\text { All ages } \\
(2)\end{array}$ & $\begin{array}{c}\text { Adults (15+ years) } \\
\text { (3) }\end{array}$ & $\begin{array}{c}\text { Children (0-14 years) } \\
\text { (4) }\end{array}$ \\
\hline Male & $\begin{array}{l}0.035^{* * *} \\
(0.005)\end{array}$ & $\begin{array}{l}0.031 * * * \\
(0.006)\end{array}$ & $\begin{array}{l}0.046 * * * \\
(0.007)\end{array}$ & $\begin{array}{r}-0.001 \\
(0.009)\end{array}$ \\
\hline Age (years) & $\begin{array}{l}0.001 * * * \\
(0.000)\end{array}$ & $\begin{array}{l}0.000 * \\
(0.000)\end{array}$ & $\begin{array}{l}0.001 * * * \\
(0.000)\end{array}$ & $\begin{array}{l}-0.005 * * * \\
(0.001)\end{array}$ \\
\hline Numerate & $\begin{array}{c}0.005 \\
(0.006)\end{array}$ & $\begin{array}{c}0.004 \\
(0.006)\end{array}$ & $\begin{array}{c}0.009 \\
(0.007)\end{array}$ & \\
\hline Anglican & $\begin{array}{l}-0.076 * * * \\
(0.005)\end{array}$ & $\begin{array}{l}-0.069 * * * \\
(0.006)\end{array}$ & $\begin{array}{l}-0.057 * * * \\
(0.008)\end{array}$ & $\begin{array}{l}-0.067 * * * \\
(0.009)\end{array}$ \\
\hline Catholic & $\begin{array}{l}-0.024 * * * \\
(0.007)\end{array}$ & $\begin{array}{l}-0.024 * * * \\
(0.007)\end{array}$ & $\begin{array}{r}-0.013 \\
(0.009)\end{array}$ & $\begin{array}{l}-0.041 * * * \\
(0.010)\end{array}$ \\
\hline Muslim & $\begin{array}{l}-0.053 * * * \\
(0.010)\end{array}$ & $\begin{array}{l}-0.048 * * * \\
(0.011)\end{array}$ & $\begin{array}{l}-0.040 * * \\
(0.014)\end{array}$ & $\begin{array}{l}-0.060 * * * \\
(0.015)\end{array}$ \\
\hline African trad. religion & ref. & ref. & ref. & ref. \\
\hline Distance (In) & & $\begin{array}{l}0.011 * * * \\
(0.001)\end{array}$ & $\begin{array}{l}0.011 * * * \\
(0.002)\end{array}$ & $\begin{array}{l}0.008 * * * \\
(0.003)\end{array}$ \\
\hline Bwamba County & & $\begin{array}{r}-0.018 \\
(0.014)\end{array}$ & $\begin{array}{r}-0.020 \\
(0.017)\end{array}$ & $\begin{array}{r}-0.004 \\
(0.028)\end{array}$ \\
\hline Patients per year & $\begin{array}{l}0.000 * * * \\
(0.000)\end{array}$ & $\begin{array}{l}0.000 \\
0.000\end{array}$ & $\begin{array}{r}-0.000 \\
(0.000)\end{array}$ & $\begin{array}{l}0.000 * * \\
0.000\end{array}$ \\
\hline Rainfall (In) & $\begin{array}{c}-0.002 \\
(0.003)\end{array}$ & $\begin{array}{r}-0.003 \\
(0.003)\end{array}$ & $\begin{array}{r}-0.001 \\
(0.004)\end{array}$ & $\begin{array}{c}-0.006 \\
(0.005)\end{array}$ \\
\hline Temperature & $\begin{array}{l}0.013^{* *} \\
(0.006)\end{array}$ & $\begin{array}{c}0.011 \\
(0.006)\end{array}$ & $\begin{array}{c}0.007 \\
(0.008)\end{array}$ & $\begin{array}{l}0.022 * * \\
(0.009)\end{array}$ \\
\hline Year FE & Yes & Yes & Yes & Yes \\
\hline Observations & 14,495 & 12,857 & 8,567 & 4,264 \\
\hline Pseudo $R^{2}$ & 0.088 & 0.092 & 0.101 & 0.116 \\
\hline
\end{tabular}

Notes: Robust standard errors in parentheses clustered at patient-level. Robust standard errors clustered at the individual level in parentheses. 78.7 per cent of STD cases are syphilis and 21.3 per cent gonorrhoea. Among STI-diagnosed adults 71.7 per cent were syphilitic (95.7 per cent children) and 28.3 per cent diagnosed with gonorrhoea (4.3 per cent children). No significant variation in results when period 1923-27 (Dr Schofield) was dropped from regression. Results are robust to doctor fixed effects. ${ }^{* * *, * *}$, *Estimate significance at $0.01,0.05,0.10$ levels, respectively.

treponemal diseases (endemic syphilis or yaws) were often mistaken for sexually transmitted syphilis in the early-mid colonial period, a thesis which seems to be supported by the association between STI diagnosis in children and locations with higher temperature. ${ }^{107}$

Multivariate regression analysis in Table 6 reveals that there was not only sharp variation in STI diagnosis between Christians and followers of traditional religion but that Anglicans were least likely to receive an STI diagnosis, followed by Muslims, then by Catholics, with Anglicans a remarkable 7.6 percentage points lower than traditionalists. These data may accurately reflect local denominational diversity in sexual behaviour.

107. N. Davies, 'The History of Syphilis in Uganda', BWHO, 1956, 15, 1052-53; Doyle, Before HIV, 8895. 
Certainly, Anglican missionaries emphasised the depravity of indigenous customs, Catholic tokenism and Muslim 'addiction' to polygamy and sodomy. ${ }^{108}$ These preconceptions, however, may have influenced, consciously or unconsciously, diagnostic practice. As one doctor serving in Uganda put it in the 1920s, 'the diagnosis ... [of syphilis was] very largely a matter of personal convention'. ${ }^{109}$ Given that CMS missionaries in particular, targeted what they perceived as a pernicious outcome of ignorance and neglect, it is likely that Toro Hospital doctors would have assumed that practices such as the deliberate inoculation of infants with syphilis in an attempt to convey some degree of immunity against later infection would have declined most rapidly amongst Anglican. As well as considering doctors' subjectivity, the possibility that patients' self-selection influenced the denominational distribution of STI diagnosis should also be examined. A central aim of the mission enterprise in Uganda was to ensure their converts came to associate STIs with sin. This was conceived primarily as a deterrent against infection, but missionary writings make it clear that individuals diagnosed with an STI were made aware of the shameful nature of their condition. ${ }^{110}$ Given the close monitoring of their congregations, which characterised the early church in Uganda, it is possible that Catholics who suspected, they might have an STI actively chose to seek treatment at an Anglican institution rather than their own nearby Virika Hospital, seeking to avoid enduring stigma and minimise moral reprehension.

This sense that STIs were a disease category where diagnosis was particularly affected by non-clinical factors is strengthened by Figure 11. Two aspects of this graph attract particular attention. The first is that the frequency of STI diagnosis varied according to the doctor in charge far more than could be explained by normal year-on-year fluctuations. The second is that some doctors were relatively much more likely than others to diagnose STIs among followers of traditional religion. Under Toro Hospital's longest-resident doctor, Bond, the proportion of STI cases remained relatively stable, with limited variation by religion. In 1911, however, he was temporarily replaced by Dr Cook, and the incidence of STls in hospital rose within 1 year among Christians from 8 per cent to 16 per cent and among followers of traditional religion from 12 per cent to 32 per cent. On Bond's return in 1912, hospital incidence returned to the levels seen previously, until the CMS Social Purity campaign, which followed the end of the First World War, saw STI diagnoses rise steadily in frequency. It is equally possible that this reflected an intensifying clinical fixation or an increase in patients self-reporting with suspected STI infection. However, while STI diagnoses were always higher among patients following traditional religion, until the early 1920s, STI patterns among Christian patients ran largely parallel. In contrast, following Bond's permanent departure in 1923, diagnoses among traditionalists rose sharply to a peak of 39 per cent in 1924 under Dr Schofield, whereas STIs among Christians fell steadily from 17 per cent to 11 per cent. Under Leakey (1927-34), hospital incidence fluctuated wildly, and rates were much higher among traditionalists. After his departure, the trend once again ran broadly parallel by religion. After 1934, as secular doctors

${ }^{108}$ Albert Cook, 'Maternity and Child Welfare Work in Uganda and Its Relation to the Birth and Death Rate', Mengo Archive, Mulago, 1933.
${ }^{109}$ Uganda, Annual report of the medical department, 1923, NA, CO/685/6, 9, 131-32.

${ }^{110}$ Albert Cook, Annual letter 1923, CMS, G3/AL 1917-1934. 


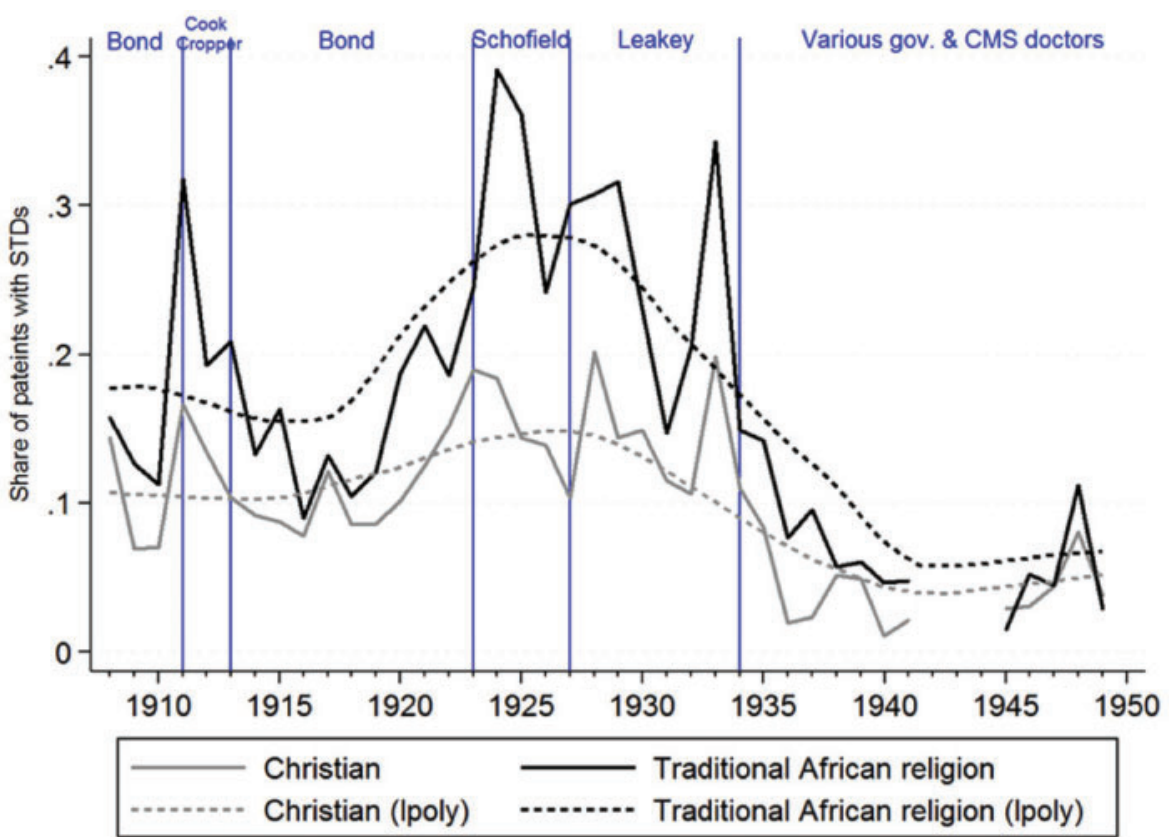

Fig. 11. Prevalence of STIs by religion and doctors' terms, 1908-49. Vertical lines mark a change in doctors' terms. Dotted lines: local polynomial smoothing line.

exerted more influence, STIs' share of cases became relatively stable at a lower level, with minor denominational variation. Given that treatment options over this period are believed to have made almost no impact on STI prevalence, and that ethnographic and mission evidence provides a sense of gradual shifts in sexual behaviour, rather than dramatic, short-term fluctuations in sexual morality, we have to assume that clinicians' subjectivity to varying degrees affected the likelihood of particular symptoms being diagnosed as an STI. ${ }^{111}$ The sense that differential religious diagnosis was particularly significant for STIs is reinforced by the absence of pronounced structural breaks within other major disease categories following the transfer of medical personnel.

Three forms of evidence support this hypothesis. First, the financial survival of medical mission depended heavily on income received for STI treatment. The CMS charged patients 400 times the cost of the drugs used in the 1920s. This unique surcharge for 'sin' enabled STI injections to cross-subsidise treatment for other conditions and caused concern that financial interest might skew diagnostic practice. ${ }^{112}$ Secondly, analysis of patient records from the 1920s at Mengo, Toro's mother hospital, found that no relationship existed between neonatal mortality and maternal histories of syphilis, which was

${ }^{111}$ Doyle, Before HIV, 139-220, 308. Nevertheless, results in Table 6 are robust to the inclusion of doctor fixed effects that capture varying diagnostic subjectivity.
${ }^{112}$ Anon, 'The Treatment of Ante-natal Syphilis in Baganda Women', 22 March 1929, Cook Archive. 
epidemiologically a most unlikely outcome. Thirdly, Michael Tuck's analysis of medical records from 1920s Uganda also indicated that clinical subjectivity influenced diagnostic decisions relating to STIs, finding that European patients with the same clinical signs and serology as Africans were less likely to be diagnosed as syphilitic. ${ }^{113}$

\section{Conclusion}

This article has sought to shed new light on the impact and experience of western biomedicine in 20th-century Africa. Analysis of mission hospital records has shown how radically various causes of admission fluctuated over time, with skin diseases, STIs and injury experiencing the greatest declines, while respiratory diseases and gastroenteritis rapidly increased in frequency after 1945. Moreover, patients' ALOS fell by almost 80 per cent between 1908 and 1970, permitting a dramatic increase in the number of patients treated within the hospital over time. In contrast, the overall cure and death rates remained largely stable over this period.

Critiques of western biomedicine have emphasised the dissonance between western biomedical interventions and indigenous conceptions of healing, characterised by pluralism, pragmatism, prioritisation of social harmony and corporate rather than individualistic therapeutic strategies. The resulting suspicions of biomedical intent challenged assumptions of a smooth epidemiological transition based on growing acceptance of preventive and curative medicine. ${ }^{114}$ In-patient registers cannot reveal the details of individual patients' journeys through alternative healing contexts nor do they provide deep insights into the psychology of patients and their families. However, this quantitative source does permit some tentative qualitative commentary on individual motivation, self-identification and medical bias in relation to the sick who chose to attend the hospital. It is striking, for example, that decades after the hospital had opened, denominationally, its patients were still extremely diverse. Followers of traditional religion made up around 30 per cent of admissions in the 1950s, just as they had in the 1910s. Catholics actively chose to attend a Protestant hospital rather than the Catholic institution located minutes away, no doubt in some cases because of embarrassment, but presumably also reflecting judgements about therapeutic quality. ${ }^{115}$ Missionisation then did not fully capture the convert, and patients experimented not only with competing medical traditions but with rival biomedical institutions. Their shorter duration of treatment suggests Muslims sought to escape intensive evangelisation as quickly as possible, but their share of admissions remained remarkably consistent, despite the opening and steady improvement of Fort Portal's secular state hospital. ${ }^{116}$ Moreover, detailed supplementary information about missionary doctors' periods of service permits for the first time analysis of their overall effectiveness and

${ }^{113}$ Michael Tuck, Syphilis, Sexuality and Social Control (Chicago: Northwestern University, 1997), 227.

${ }^{114}$ Steven Feierman, 'Explanation and Uncertainty in the Medical World of Ghaambo', BWHO, 2000, 74, 317-44; J. Janzen, The Quest for Therapy in Lower Zaire (Berkeley: University of California Press, 1978). Cf. Luise White, Speaking with Vampires: Rumor and History in Colonial Africa (University of California Press, 2000).
${ }^{115} \mathrm{~A}$ more complete understanding of patient choices would require access to the patient records of Virika Catholic hospital.

${ }^{116}$ It is possible that some Muslims preferred healing within a religious context, even one alien to their own beliefs, over secular medicine, potentially because of perceptions around care as a vocation. 
especially their assumptions about the prevalence of specific diseases among different social groups.

In particular, our data from Toro reinforce previous studies showing that medical missionary strategy and practice in Africa was dominated by a fixation with sexual immorality, with illness imagined as a manifestation of spiritual corruption, and Africans as inherently diseased and sinful. ${ }^{117}$ What the Toro results contribute is a new understanding of how STI diagnoses may have been influenced by missionary concerns about immorality, and how the tendency to diagnose STIs, and to diagnose differentially between converts and followers of traditional religions, varied sharply by individual clinician. Within the broad missionary fixation with STIs, individual subjectivity was highly significant.

In no other disease category was apparent clinical bias easily detectable. In general, the data analysis indicates that Anglican converts were significantly healthier than nonAnglicans, measured by cure, mortality and length of stay. Conversion seemed to reduce the frequency of some conditions, notably skin ulcers, but surprisingly, we observed no religion-specific effects concerning the pattern of diagnosis of hygiene-related infections, nor that mission school education, proxied through age-heaping, lowered Christian patients' relative risk of STIs and hygiene-related diseases. This challenges the effectiveness of missions' hygiene propaganda or suggests that secular public health information was broadly effective throughout the population regardless of Christian conversion and access to formal education. The findings may also reinforce the sense that Christian identities in Uganda over this period were neither absolute nor unchanging.

These patient registers then provide new insights into changing patterns of morbidity over time in rural Africa. They indicate that increased efficiency and engagement with the hospital's rural hinterland enabled its staff to treat ever-larger numbers of patients, of all ages and religions, drawn from a remarkably large geographical range. The registers also increase our understanding of patients' context and connections and demonstrate missionary medicine's heterogeneity. These findings imply the need for further study. Toro Hospital is not unique in Africa in its retention of patient records from the colonial period. Further comparative microstudies would be valuable in demonstrating variation in longitudinal trends in disease incidence and outcomes within hospitals over time and by region and religion.

\section{Supplementary material}

Supplementary material mentioned in the text is available at www.shm.oxfordjournals. org.

\section{Acknowledgememts}

We are grateful to seminar audiences at WEHC 2015 (Kyoto), AEHN Annual Meeting 2015 (Wageningen University), ESSHC 2016 (University of Valencia), BSPS Conference 2016 (University of Winchester), ASAUK Conference 2016 (University of Cambridge), Public Health Seminar (London School of Hygiene \& Tropical Medicine), Research

${ }^{117}$ Vaughan, Curing, 77-84. 
Seminar (Mountains of the Moon University, Uganda) and RESEP Seminar (Stellenbosch University). We gratefully thank Gareth Austin, Michiel de Haas, Doreen Kembabazi, Edward Kerby, John Manton, Alexander Moradi, Derek Peterson, Valeria Rueda, Gerardo Serra and Kathleen Vongsathorn, as well as three anonymous reviewers for their helpful comments. We are particularly thankful to Bishop Reuben Kisembo of Ruwenzori Diocese and Hellen Balinda, Administrator of Kabarole Hospital, for granting us permission to conduct this research. We thank Benard Asiimwe and Isumail Muhemba of Mountains of the Moon University in Uganda for excellent research assistance. Ethical clearance was provided by the University of Sussex. Felix Meier zu Selhausen gratefully acknowledges the support of his British Academy Postdoctoral Fellowship (pf160051) project 'Conversion out of poverty? Exploring the origins and long-term consequences of Christian missionary activities in Africa'. 